\title{
FROM CIVIL SOCIETY'S PRIVATIZATION AND DEPOLITICIZATION TO THE CENTRALITY OF THE POLITICAL PRAXIS: ON THE DIFFERENCE AND OPPOSITION BETWEEN PUBLIC-POLITICAL AND PRIVATE IN LIBERAL POLITICAL THEORIES AND INSTITUTIONALIZED AND UNIVERSALIST RELIGIONS
}

\author{
[ DO PRIVATISMO E DA DESPOLITIZAÇÃO DA SOCIEDADE CIVIL À CENTRALIDADE DA PRÁXIS POLÍTICA: \\ SOBRE A DIFERENÇA E A OPOSIÇÃO ENTRE PÚBLICO-POLÍTICO E PRIVADO EM TEORIAS POLÍTICAS \\ LIBERAIS E EM RELIGIÕES INSTITUCIONALIZADAS E UNIVERSALISTAS ]
}

\author{
Leno Francisco Danner Correio * \\ Universidade Federal de Rondônia (UNIR) \\ Agemir Bavaresco Correio ** \\ Pontifícia Universidade Católica do Rio Grande do Sul (PUCRS) \\ Fernando Danner Correio *** \\ Universidade Federal de Rondônia (UNIR)
}

\begin{abstract}
This paper criticizes (a) the separation between public-political versus private and unpolitical performed by liberal political theories, which constructs a very unclear and depoliticized sphere, subjects, values and practices that cannot be accessed neither by political-juridical institutions nor by social movements, citizen initiatives and politicalcultural minorities, undermining a direct, participative and inclusive democratic political praxis as the basis of social criticism, cultural resistance and political emancipation by the very emphasis on the unpoliticity and privatization of civil society, its subjects, practices, values and clashes; (b) the political fundamentalism of institutionalized and universalist religions, which imposes the unpolitical private on the social, political, cultural and institutional sphere, from the delegitimation, silencing and marginalization of the differences, of the political praxis as a social struggle between opposed and different voices. We will propose that the possible way and strategy for a critical social theory and an emancipatory and inclusive democratic political praxis in face of this consolidated depoliticization of the praxis, civil society and institutions is to deconstruct such a separation between public-political and private by the politicization of civil society, its subjects, struggles, values and practices, which means that the foundation and application of a political theory into the social depends on the affirmation of the centrality of civil society's political subjects and social clashes. Here, the praxis as politicity, carnality and permanent-pungent struggle and, as a consequence, the centrality of nowadays social-political subjects become the core of the theoretical-practical
\end{abstract}

Resumo: No artigo, nós criticamos (a) a separação entre público-político versus privado e apolítico levada a efeito por teorias políticas liberais, que estabelece uma esfera, sujeitos, valores e práticas altamente obscuros, os quais não podem ser enquadrados nem pelas instituições jurídico-políticas e nem por movimentos sociais, iniciativas cidadãs e minorias político-culturais, o que prejudica uma práxis política democrática que deve ser direta, participativa e inclusiva como base da crítica social, da resistência cultural e da emancipação política, a partir da ênfase na apoliticidade e na privatização da sociedade civil, de seus sujeitos, de suas práticas, de seus valores e de suas lutas; bem como (b) o fundamentalismo político das religiões institucionalizadas e universalistas, que impõe o seu privatismo apolítico e despolitizado às esferas social, política, cultural e institucional, por meio da deslegitimação, do silenciamento e da marginalização das diferenças, da práxis política como luta social entre vozes opostas e diferenciadas. Nossa proposta consiste em que o caminho e a estratégia possíveis para uma teoria social crítica e para uma práxis política democrática emancipatória e inclusiva, em face desta consolidada despolitização da práxis, da sociedade civil, de seus sujeitos, de suas lutas, de seus valores e de suas práticas, consiste em desconstruir a separação entre público-político versus privado por meio da politização da sociedade civil, de seus sujeitos, de suas lutas, de seus valores e de suas práticas, o que significa que a fundamentação e a aplicação de uma teoria política no social depende da afirmação da centralidade dos sujeitos políticos e das lutas sociais sediados na sociedade civil. Aqui, a práxis como politicidade, carnalidade e permanente-

\footnotetext{
* * Doutor em Filosofia (PUCRS). Professor de Filosofia e de Sociologia no Departamento de Filosofia da Fundação Universidade Federal de Rondônia.m@ilto:leno_danner@yahoo.com.br.** Doutor em Filosofia (Université de Paris I - Pantheon Sorbonne). Professor de Etica e de Filosofia Politica no Departamento de Filosofia e no Programa de Pós-Graduação em Filosofia da Pontifícia Universidade Católica do Rio Grande doSul(PUCRS).m@ilto: abavaresco@pucrs.br.***Doutorem Filosofia (PUCRS). Professor de Filosofia no Departamento de Filosofia da Universidade Federal de Rondônia (UNIR). m@ilto: fernando.danner@gmail.com
} 
grounding and in terms of its link with the social sphere, subjects and clashes.

KEYwORDS: Liberalism; Institutionalized and Universalist Religions; Differences; Public-Private; Social Struggle

\section{ITRODUCTION}

Tet us start with the very epistemological-normative basis of contemporary ethicalpolitical theory regarding Western democratic societies, which is the fact of pluralism generated by modern religious wars resulted from the Protestant Reform. Indeed, for contemporary ethical-political theory, the Protestant Reform was one of the more fundamental and impactful facts of and for modern European society and, after, of and for Western societies in the process of modernization. It is so important in political, cultural and normative terms that John Rawls placed it as the basis of his theory of justice as fairness, since it allows, by the consolidation of pluralism as the public soil and normative framework of Western democracies, the justification of the ideas of a pure democratic political theory, of pluralism or multiculturalism as the basis of such a pure political theory (because, in the first place, multiculturalism is a fact of the contemporary democratic societies - or even beyond) and of an overlapping consensus that constitutes the liberal political response to the fact of pluralism (Rawls) or, using Habermas's terms, to the post-metaphysical age. Here, the fact of pluralism or the post-metaphysical age means the falling of the correlation among strong institutionalism, strong anthropologicalontological, social-cultural and epistemological-political objectivity and essentialist and naturalized foundations as the ground and the dynamic of the constitution, legitimation and streamlining of democratic political-juridical institutions and of the consequent political, juridical, constitutional and cultural background and framework of democracy. In other words, if pluralism is our more central and pungent contemporary fact, it puts down all the essentialist and naturalized bases, values, practices and authorities as the common ground of the socially binding public and political soil, institutions, values, practices and authorities, requiring in return the most political posture we can assume as democratic citizens, groups, culture and institutions.

Such a discussion, of course, presupposes a direct separation between public-political sphere, values, practices and subjects and private spheres, values, practices and subjects, between a public-political context, subject and action and a non-political and non-public context, which is not so clear or easy to perform. In this case, Rawls's veil of ignorance is totally comparable to Habermas's discourse circle. If Rawls establishes a formal situation in which the context, the epistemological-political subjects, the practices and the values of the foundation are apolitical or depoliticized, blind and unlinked in relation to the carnality, politicity and belonging of the praxis as condition of a pure political theory and of an objective-intersubjective notion of social normativity (that is, the radical separation between what is public-political and what is merely private, non-public, non-political), that can answer and seriously consider the fact of pluralism; Habermas, in the same dynamic, assumes, on the one hand, that in the discourse circle the context is politicized and the epistemological-political subjects can discuss about everything, but, on the other hand, they can discuss about everything with the condition that they must argue from impartial, neutral, formal and impersonal values, practices and arguments, which means that they cannot assume their carnality, politicity and belonging as the condition of the foundation both of a political theory of democracy and of the objective-intersubjective notion of social normativity. Both in Rawls and in Habermas the tension between public-political values, practices and subjects and private spheres, practices, values and subjects is the theoretical motto, ignoring that such a separation does not exist in reality: only the permanent participation and the pungent oppositions can allow the construction of a minimal political agreement regarding political institutions, democratic culture and social-political actions and vindications-because the separation between public-political and private-apolitical is a political-normative option which becomes hegemonic only politically, only by political action of the hegemonic social-political classes that assume it as basis of their social-political role (Rawls and Habermas conceive of this separation as if it were natural or evident and apolitical, which determines the sense and the way of their theories, as we will see throughout the paper).

The struggles for recognition and the political-cultural-religious fundamentalism in current social, political, cultural and institutional dynamics have shown that the politicity, 
carnality and public link of the institutions of civil society, of their subjects and clashes are the basis of the understanding, legitimation and streamlining of the institutional movements and decisions, including the role, the core and the postures of institution's authorized epistemologicalpolitical subjects regarding civil society's multiple informal subjects, practices, values and struggles. Now, this direct and pungent correlation between institutions and civil society, formal (or institutional) epistemological-political subjects and informal (non-institutionalized) epistemological-political subjects is totally political and becomes the very theoretical-normative framework from which we can access both public-political institutions and civil society's sphere, subjects, practices, values and clashes. More: the fact that there is not a pure or strict or direct separation between public-political and private, between juridical-political institutions and civil society's private institutions, between political praxis and a liberal apolitical-depoliticized sphere, as we think, points to a necessity of reconstruction of the political theory from the overcoming of the difference and contraposition between public-political and private, which leads, as a consequence, to the understanding that civil society's epistemological-political subjects and struggles are the only basis, value and subject of the institutional constitution, legitimation and evolution.

In this paper, we will argue for the impossibility of grounding a political theory on the separation between public-political sphere, practices, values and subjects and private sphere, practices, values and subjects for a double reason. First, such a separation, politically speaking, is based on an impossible correlation and mutual support between what is political and, therefore, what can be criticized, framed and changed, and what is unpolitical and, therefore, totally untouchable. But who decides what is political and what is not? Because there is not a natural, evident and apolitical frontier, separation and delimitation between political sphere and private sphere; it is constructed politically by opposed social-political classes, their struggles, hegemonies and counterpoints. On the other hand, such a point, as we can see, makes explicit the fact that the barrier between the public-political and the private and unpolitical constructs a very unclear, technical, unpolitical and impersonal sphere, linking, subject, practice and value regarding what is private which does not allow the real politicization of social movements, citizen initiatives and political-cultural minorities, harming their effective role and action regarding institutions, harming also its institutional politicization and in relation to private civil society. These political subjects become peripheral exactly because they criticize and politicize what is not political, what is mainly technical, impersonal and private, after all what is criticized by them is the private sense, constitution and link of civil society, its epistemological-political subjects and their social, political, cultural and institutional role regarding the public-political itself and the very differences.

Second, the separation between public-political and the private, between politicaljuridical institutions and civil society's unpolitical institutions and subjects leads to the fact that institutionalized and universalist religious assume a political role that, on the one hand, breaks with this separation and opposition, but, on the other, performs it from the idea that the private must be imposed on the public-political, in a movement that ignores the differences as basis of the political. Institutionalized and universalist religions, therefore, have the tendency to depoliticize the political by the imposition of the private creed on the social sphere and for everybody, while liberal politics has the tendency to separate the public-political and the private and, as a consequence, to strongly depoliticize the private, creating an unclear area of the social that is unpolitical and conservative. From the development of these arguments, the paper will propose three basic ideas as criticism and reconstruction both of the liberal separation between public-political and the private and unpolitical, and of the institutionalized and universalist religions' imposition of the unpolitical private on the public-political as public-political. The first idea is that liberal political theory must be corrected in its utilization of the correlation and contraposition between public-political and the unpolitical, impartial, neutral, formal and impersonal proceduralism as basis of understanding, framing and constructing a political theory and a notion of social normativity for pluralism, based on it. The second idea is that institutionalized and universalist religions must overcome the imposition of the unpolitical and uncritical private into the political, the unpolitical private as the basis of the political, because this depoliticizes the differences and their clashes, conceiving of them not only as a natural-cultural error, but also as a non-important subject, value and practice which, in this situation, can be muted or substituted by the institutionalized and universalist religious-cultural institution, as denied in their singularity and massified-standardized. Third, as an alternative, it is necessary to overcome the separation between public-political and the private-apolitical from the centrality of a political, carnal and linked civil society which is characterized by many concurrent social- 
political subjects that establish a very pungent and permanent struggle with a public-political core, role, link and sense. Here, therefore, the private is totally political, carnal and normative, and it politicizes the public-political institutions, subjects, practices and values, in a way that requires exactly the unstoppable and dramatic criticism and inclusive participation as a counterpoint both to liberal apoliticity and fundamentalist totalitarianism.

\section{Political Liberalism AND THE DePOLITICIZATION OF CIVIL SOCIETY: ON THE SEPARATION BETWEEN PUBLIC-POLITICAL AND THE PRIVATE-APOLITICAL AND ITS POLITICAL-INSTITUTIONAL CONSEQUENCES}

Rawls's political liberalism reads the Western modernization as a process of constitution of the correlation among pluralism, individualism and democracy which finds its place in the ideas of the democratic rule of law, individual rights, civic culture and constitutional structuration (see Rawls, 2000c, pp. 45-90). In this process, the Protestant Reform is understood from an epistemological-political standpoint that conceives of it as a very important historical and normative fact to the consolidation of these basic characteristics of a Western democratic society (see Rawls, 2000c, pp. 24-38). If Protestantism instituted the religious-cultural difference as the basis of the constitution of European modern societies, putting it as a public-political fact, the consequent European war between religions led to the progressive consolidation of pluralism, personal freedom and individual rights as the very nuclear core of this model of Western democratic societies (see Rawls, 2003, §1, pp. 01-06). Yet, according to Habermas, such a kind of process of Western modernization, because of the correlation between pluralism and individualization, gradually consolidated social-cultural rationalization as the ontogenetic basis for the constitution of modern society-culture and of modern cognitive-moral consciousness, substituting essentialist and naturalized foundations, values and authorities with democracy, citizenship and the rule of law as the ground and dynamic of the public-political culture, a secular and rationalized public-political culture that sustains itself in and by permanent social criticism, civic participation and juridical-political institutionalization (Habermas, 2012a, pp. 20-28, p. 87, pp. $94-168$, p. 299, pp. 383-385; Habermas, 2012b, p. 87, pp. 141-202; Habermas, 2002a, pp. 8387; Habermas, 2002b, pp. 477-483; Habermas, 2003a, p. 13, pp. 22-25, p. 61, pp. 233-234; Habermas, 2003b, pp. 186-187). Now, it is from such a contribution of modernity-understood by Rawls and Habermas (or even Honneth and Forst) from the affirmation of pluralism, individualism and secularization in cultural-normative terms - that the ethical-political foundation in current times must be based on and streamlined (See Rawls, 2003, p. XVIII-XIX; Habermas, 2012b, p. 525; Habermas, 2002a, p. 53; Habermas, 1990, pp. 11-63; Honneth, 2003, pp. 274-275; Forst, 2010, p. 46, pp. 68-110).

First of all, therefore, our current age is the moment of pluralism, the age of the postmetaphysical condition as the more basic consequence of Western modernity, and this means the privatization of the comprehensive doctrines (which are understood directly as essentialist and naturalized foundations) in terms of framing, grounding and orienting the public-political sphere, and socially binding institutions, subjects, values and practices. In the post-metaphysical age, in the age of pluralism, what is essentialist and naturalized is transposed to the private sphere, becomes part of the private sphere; on the other hand, politics becomes rationalized, secularized and profane, depending on the intersection of rationalization, secularism, participation and individualism, which are the alternative to the essentialist and naturalized foundations (see Rawls, 2000b, pp. 245-290; Rawls, 2000c, pp. 134-176; Habermas, 2002a, pp. 17-22; Habermas, 2002b, pp.03-54). That is the reason why both Rawls and Habermas speak about a political and rational praxis of foundation of the notion of social normativity and of the democratic institutions, a kind of pure political praxis that is overlapped to current subjects, values, practices and struggles, highly purified of the current belongings (perceived as part of the essentialist and naturalized worldviews). In other words, if only a political and rationalized theory, secular and profane, is the fundamental way and alternative to the post-metaphysical era as the overcoming of the essentialist and naturalized basis in terms of public-political culture, politics and institutions, then such a theory must be pure, refined regarding all that is not political (see Rawls, 2000b, pp. 201241; Rawls, 2003, §5, pp. 17-19; Habermas, 2002a, pp. 17-53; Habermas, 1990, pp. 37-63; Habermas, 1989, pp. 61-132).

Now, what conditions, requirements and practices are posed by this correlation of pluralism, individualism and secularization in order to achieve a foundational epistemological, 
political and normative paradigm which is adapted to the post-metaphysical age, a paradigm which is purely political, rationalized, secularized and profane? First and most basic of them: the end of the metaphysical-theological foundations, values and authorities as basis of the publicpolitical culture, practices, values and institutions, that cannot serve as way, content, value and subject of the public-political foundational praxis. According to Rawls, the comprehensive doctrines cannot be used and imposed on the public-political sphere as public-political sphere because they do not allow the intersubjective agreement with each other. One will not renounce her/his own vital position in order to accept any other vital position as societal, political, institutional and normative core, so a particular and private comprehensive doctrine has no capability to assemble, motivate and justify the rest of the comprehensive doctrines in terms of the validity and importance of the public-political institutions, values, practices and subjects defined in the foundational process (see Rawls, 2000a, §§ 22-24, pp. 136-153; Rawls, 2003, §6, pp. 20-25). According to Habermas, essentialist and naturalized bases prevent the postconventional or decentered stage of epistemological-moral consciousness which is typical of and generated by European cultural modernity, characterized by a non-egocentric and nonethnocentric posture that leads directly to universalism, that is, to the capability of putting oneself in the shoes of others. A person and a social-cultural group that act from essentialist and naturalized codes, values and practices cannot assume a universal position because, here, they cannot think, act and legitimize intersubjective norms and relations in a formal, impartial, neutral and impersonal way, with generic concepts, values and practices - individuals and groups who use essentialist and naturalized bases will frame the public-political in particular and the differences in general from the very private essentialist and naturalized bases that they have (see Habermas, 2012a, pp. 90-142; Habermas, 2003a, p. 20, p. 44; Habermas, 2002a, pp. 07-08; Habermas, 2002b, pp. 01-02; Habermas, 1990, pp. 11-63; Habermas, 1989, pp. 61-132). As a consequence, for both Rawls and Habermas, the intersubjective justification is not possible from essentialist and naturalized bases, because they do not enable individual reflexivity and, more important, the recognition of otherness, which is not accessed by comprehensive doctrines at all, but only by an impersonal, impartial and neutral politics grounded on the rationalization of the praxis and values - here, it is not a coincidence that for both Rawls and Habermas, rationality is the most basic posture of the foundation in the age of pluralism, since it requires, in the original position or in the discourse circle, a high degree of depoliticization, depersonalization and formalism regarding practical subjects, differences of status, social struggles and culturalreligious belongings (see Rawls, 2000a, $\$ \$ 22-24$, pp. 136-153; Rawls, 2000c, p. 261-306; Rawls, 2003, §06, pp. 36-40; Habermas, 2012a, pp. 20-87; Habermas, 2002a, pp. 92-116; Habermas, 2002b, pp. 468-481; Habermas, 1989, pp. 17-34).

The second condition of a political-normative theory for and adapted to the fact of pluralism or to the post-metaphysical age is exactly its purity, depersonalization, impartiality and neutrality regarding the different and even opposed comprehensive doctrines. A democratic political theory should not be compromised with or dependent on essentialist and naturalized foundations, because, as we said above, they do not allow individual reflexivity and intersubjective reciprocity, defining from a religious, cultural and biological standpoint (once and for all) the status quo, the understanding and the relations with the differences and, finally, the sense and the constitution of the public-political sphere and institutions (see Rawls, 2003, §06, pp. 20-25; Rawls, 2003, §§08-11, pp. 34-53; Habermas, 2002a, pp. 20-53, pp. 291-292; Habermas, 1989, pp. 143-222; Forst, 2010, pp. 38-46). As a consequence, if a political theory is based on essentialist and naturalized foundations, then it is totalitarian and leads to a direct, uncritical and violent standardization and depoliticization of the differences, of the publicpolitical as the place of the differences, as the action of the differences about themselves. A democratic political theory must be independent and overlapped to essentialist and naturalized positions, that is, it must be capable of, by using only social interaction, rational arguments and the power of the majority, justify itself by its disengagement and depoliticization concerning comprehensive doctrines (see Rawls, 2000b, pp. 201-241; Rawls, 2000c, pp. 179-219; Rawls, 2003, §26, pp. 125-133; Habermas, 2003a, pp. 22-24, p. 87; Habermas, 2002a, pp. 17-53 pp. 94118; Habermas, 2006). Therefore, a political theory for democracy and pluralism must be an unpolitical and depersonalized theory: it cannot assume politicity that confronts from publicly accepted models of good life the comprehensive doctrines, because that would make it a comprehensive doctrine as well (cf.: Rawls, 2000a, §§20-26, pp. 127-173; Rawls, 2000b, pp. 293-331; Rawls, 2000c, pp. 261-306; Rawls, 2003, §§113-137; Habermas, 2003a, p. 87; Habermas, 2002a, pp. 17-53, pp. 92-116; Habermas, 1989, p. 61-132); it cannot take carnality, since this would transform it again into a substantive theory as a comprehensive doctrine typical 
of civil society; it cannot be linked to social, cultural and political subjects of civil society, because that would make it a private comprehensive doctrine as the others. For short, a democratic political theory which is adapted to and promotes pluralism must be unpolitical, depoliticized, depersonalized, impartial and neutral, independent and overlapped with pluralism. It is non-political as a condition for the foundation of a political theory; it is depersonalized as a condition for the grounding of a personalized theory; it is totally standardized (in the original position and even in the discourse circle the differences are erased and/or silenced) as the condition for the construction of a normative-political theory for the differences.

And here comes the third condition for the foundation of a political theory for democracy in the age or pluralism, that is, the understanding and the use of pluralism as an unpolitical fact, as a depoliticized content and practice. Now, what is more impressive in Rawls's and Habermas's liberal political theories is exactly this idea-consequence that pluralism cannot be assumed and conceived of from a very political standpoint, because it is exactly the politicity, carnality and personalization of pluralism that lead to the impossibility of both the foundation of a pure political theory and of a notion of social normativity binding for all, as the valid argumentation, interaction and agreement between the multiple comprehensive doctrines with each other on common values, practices and institutions. Here, pluralism as motto and ending point of a pure political theory requires and points to a non-political and depersonalized sense of pluralism itself, because only that would allow the theoretical-practical independence of democracy regarding essentialist and naturalized doctrines. In this case, taking pluralism seriously means not conceiving of it as a political fact which requires a great deal of politicity, carnality and sensibility in terms of praxis, in terms of constructing a social interaction between the different epistemological-political subjects which is streamlined by the unveiling of the contradictions and the pungency of the social struggles for hegemony between them. It seems that, in Rawls's and Habermas's political theories, the politicization of pluralism would lead to the delegitimation and destruction of pluralism, as if the politicization of it were not a public-political option and action which could guarantee the political theory and the social normativity based on and promoter of pluralism. In this case, to promote pluralism as the very public-political fact, basis, content and dynamic of and for the theoretical-practical foundation and paradigmatic-institutional application means to depoliticize and depersonalize it in a way that it has no carnality, politicity, linking and voice - that is, indeed, the real meaning and implication of the juridical-political procedural paradigm assumed by Rawls and Habermas as method and praxis of the ethical-political foundation publicly and socially binding. Here, the differences are put in the same situation, massified and nullified by their silencing, depoliticization and depersonalization as differences; here, the political agreement regarding a binding notion of social normativity is achieved by the deletion of the politicity, carnality and linking of the epistemological-political subjects, context, practices and values of and for the foundation. The unpolitical pluralism becomes the motto, the basis, the dynamic and the subject of a political theory for democracy and pluralism which is defined from a depoliticized, depersonalized and decharacterized subject, context, practice and value marked by the deletion of differences, by the silencing of the contradictions and struggles, and therefore for the complete standardization and massification of all subjects, conditions, values, practices and dynamics, as if all were in the same boat and with the same conditions, as if the theoretical and the practical lives, subjects and actions were not totally linked, political and carnal, as if a very peaceful current situation could serve as a paradigmatic starting point and normative orientation to the political-institutional grounding by depersonalized, decontextualized and depoliticized subjects and foundational conditions. Now, what is impressive about Rawls's and Habermas's political theories is that, on the one hand, they intend to formulate a correlation of a pure political theory and a very generic notion of social normativity that is based on and promoter of pluralism, but, on the other hand, in order to achieve that, they depoliticize, depersonalize and decontextualize the conditions, the subjects, the practices and the values of the public-political foundation, which means that in the end pluralism is not the good thing and the more explosive product of Western modernization, but a real problem for the agreement, for the praxis, since, if it is affirmed directly, it cannot furnish a basis of agreement between the differences. So, pluralism is only the object and the goal for theoretical foundation and practical application if it is depoliticized, decontextualized and depersonalized, as we said above, and that means that pluralism is a negative thing for politics, for praxis. Here, only by its negation it is possible to ground and streamline a political theory and a binding notion of social normativity for the social-political subjects and their clashes in current life.

Therefore, here we have the fourth condition for the construction and foundation of a democratic political theory and a notion of social normativity for pluralism, based on it, which is 
the fact that the subjects, the context, the practices and the values of the foundational praxis must be free of carnality, politicity and social-cultural-political linking. In the foundational praxis, therefore, there must be no voices, no differentiations, no struggles and, as a consequence, a complete situation of peace, indetermination, depoliticization and depersonalization as the fundamental condition and dynamic for the theoretical agreement and its consequent institutional application in terms of an impartial, neutral, impersonal and formal institutionalism. In Rawls's original position, the veil of ignorance as a depersonalized, depoliticized and decontextualized condition and orientation for the construction of a pure political theory and a generic notion of social normativity defines a very undeterminated situation regarding social, cultural and political linking, regarding status quo, that establishes, as a consequence, a very unpolitical, generic and standardized subject of foundation that is not carnal and related to practical positions, as is massified in such a high intensity that the interaction is not necessary at all as the procedure of discussion and decision in terms of which conception of political justice and its values, practices and institutions will be constructed and defined by the participants of the original position. In this case, in this depoliticization, decontextualization and depersonalization of the context of foundation and, as a consequence, in this complete massification and standardization of the subjects of foundation, democracy, dialogue, discussion and interaction are not necessary, because all subjects are and think as one single subject, which means that there is no politicity, carnality, differentiation and, therefore, democracy in the political theory based on and defined by impartiality, neutrality, formality and impersonality regarding practical subjects, struggles, values and situations - an a-historical and hypothetical political theory, dependent on depersonalized, decontextualized and depoliticized subjects, and deleting the clashes and practices of Realpolitik, does not need democratic participation and inclusion, since this is not central to the construction and application of the theory itself, so the philosophy-philosopher in the ivory tower can establish the political conception and the notion of social normativity in the name of all and for all. In the last instance, even the political theory is not political, because it has depoliticized, decontextualized and depersonalized the arena, the process and the subjects of foundation, silencing and muting their voices, erasing and deleting their differences and struggles, eliminating the effective mottos and bases for any possible agreement, which are the subjects of foundation, totally politicized, carnal and linked, with their social, cultural and political belongings, their struggles against one another for hegemony, the power of their oppositions etc.

In the same sense, Habermas's discourse circle requires the rationalization of the belongings, the abstraction of the context from which the subjects of the foundation are inserted and dependent on, which also means the necessity of depoliticization, decontextualization and impersonality as a condition for a non-egocentric and non-ethnocentric cognitive-moral posture that is universalist. Universalism, in truth, is achieved from independization and overlapping regarding practical connections, from a non-political and non-carnal action which separates the epistemological-political subjects from their status quo, cultural, social, political, religious and economic belongings, requiring, as a consequence, the silencing and deletion of the differences, oppositions and clashes that pervade nowadays societal-cultural-institutional dynamic of constitution, legitimation and evolution. For Habermas, therefore, the same as Rawls, only an impartial, neutral, formal and impersonal context, subject and praxis of foundation can guarantee the epistemological objectivity, the political-normative validity, the moral universalism - that is the direct consequence of their impartial, neutral, formal and impersonal juridical-political procedural paradigm. Politicized subjects and contexts, carnal belongings and direct and effective social, political and cultural struggles-associated by them with comprehensive doctrines and, therefore, with the private and unpolitical sphere of civil society - are only particular and lead to a very closed, particularized and non-critical perspective. Now, it is by the overcoming of politicity, carnality and contextualization, it is by the massification and standardization of the subjects, contexts, practices, processes and values of the foundation that a political theory and a normative paradigm are based on and constructed; it is only from impartial, neutral, formal and impersonal subjects, contexts, practices and values that universalism is reached effectively, serving all because assuming all, constructed by all. However, in this case, all subjects, contexts and practices mean only one subject, one context and one practice, because there was a huge massification and standardization of them, which led to a powerful depoliticization, decontextualization and depersonalization of the differences, of the status quo, of the consequent struggles between opposed epistemological-political subjects. Here, a political theory for Western modernization assumed such a formalist and non-historical level and constitution that it has lost any possibility of criticism, politicization and emancipation, becoming uncritical and ineffective by depoliticizing, decontextualizing and depersonalizing the subjects, the contexts, the practices 
and the values of the foundation, massifying and standardizing them. Here, once more, democracy is not required, since this massification-standardization and the decontextualizationdepoliticization of the social sphere of foundation lead to a pure model of subject and of the context of and for the foundation, eliminating the differences, the social-political subjects, their oppositions, clashes and hegemonies that ground and streamline politics, that makes political praxis totally necessary for societal-institutional constitution, legitimation and evolutioninstitutionalism is sufficient for the foundation-validation, and it substitutes the politicization of the social-political subjects and the centrality of the praxis.

Indeed, the fifth (unpolitical) condition for the construction, foundation and application of a political theory for pluralism, a political theory based on the unpolitical pluralism, is the affirmation of the impartial, neutral, formal and impersonal juridical-political procedural paradigm as way and praxis of the intersubjective interaction. This kind of proceduralism with no politicity, carnality, contextualization, linking and personalization points to the necessity of an ahistorical and hypothetical context, subject, practice and value for the foundation of a political theory which intends to regulate and frame practical situations, that is, historical, political and carnal subjects, practices, values and relations-struggles. Now, the juridical-political procedural paradigm, from these characteristics of impartiality, formality, neutrality and impersonality, uses and reinforces the four previous conditions mentioned and developed above, defining the negative sense of pluralism and the consequent necessity of depoliticizing, decontextualizing and depersonalizing the subjects, the context, the practices and the values of the foundation with the aim of achieving a form of liberal social contract that avoids all material conditions of real societies, peoples and struggles, all conditions of current status quo and the role-core of the differences, their oppositions, contradictions and clashes. In this case, it is not demanded for a critical social theory or a democratic political praxis the knowledge of nowadays social, political, cultural, economic, religious etc. situations, the knowledge of the current epistemologicalpolitical subjects of the praxis. It is sufficient a theoretical stylization that is overlapped and autonomous concerning historical, societal and institutional subjects, contexts, practices and values, a hypothetical situation with no carnality, politicity and personalization, so that these subjects, their differences, practices and struggles are erased from the context and as condition of the foundational praxis - the subjects, the context and the practices are pacified by massification and standardization, by their depoliticization, decontextualization and depersonalization. As we said above, the impartial, neutral, formal and impersonal juridical-political paradigm establishes and demands that a political theory for a pluralist and democratic society be grounded on and streamlined from an initial condition of depoliticization, decontextualization and depersonalization of the arena, subjects, practices and values involved in such a public process of construction and legitimation. So, as a consequence, in the last instance, as we have also argued above, this kind of political theory based on unpolitical conditions, subjects, values and practices does not need effective participation, as it does not seriously assume the social, political, cultural, economic and religious differences as starting point to think, ground and apply a political justice institutionally supported into the society as a whole, with the purpose of integrating and orienting all citizens and social-cultural groups and of correcting social, cultural and economic inequalities. But how is it possible to propose this theoretical-practical model directed toward social integration and correction from a political standpoint, institution and subject if the conditions, the subjects, the practices and the values of the foundational process are depoliticized, decontextualized and depersonalized?

Likewise, the depoliticization, decontextualization and depersonalization of the context, subjects, practices and values of the foundation make explicit that citizens and social-cultural groups cannot be effectively democratic, rational and open to the differences if they really know how they are in the real world which they are constructing or from where they are located, since Rawls's and Habermas's social contracts start exactly from the autonomization and overlapping of the intersubjective interaction and argumentation regarding material dependences, belongings and personalization as condition for epistemological objectivity and political agreement, a methodological-programmatic process that requires complete abstraction of the current social, political and cultural context, as well as of its subjects, practices, values and struggles. And more: Rawls's and Habermas's political theories ignore that any possible agreement or social and moral learning are viable and consolidated only from the conflictive relations that are generated by pluralism, by the radical differentiation of the social-political subjects, with their values, practices and projects of hegemony, including their reciprocal clashes (cf.: Honneth, 2003, pp. 257-268; Danner, Bavaresco \& Danner, 2017, pp. 53-91). Here, it is not the depersonalization, decontextualization and depoliticization that would lead to agreement, learning and objectivity- 
intersubjectivity, but exactly the facing of the contradictions between the multiple social-cultural groups, which means taking in a very serious and political-normative sense the social, cultural, political, economic and religious differentiation of a specific society. Here, political theory cannot abstract or delete or silence about a sociological-historical reconstruction of the real subjects, contexts, practices, values and struggles that go to public-political space and demand a political approach and framing. Therefore, the impartial, neutral, formal and impersonal juridical-political proceduralism as method and praxis of the political-normative foundation for a democratic and pluralist society or for a post-metaphysical age in fact depoliticizes, decontextualizes and depersonalizes the contexts, the subjects, the struggles, the practices and the values of Realpolitik submitting it to a hypothetical and a-historical condition that silences, deletes and mutes about practical subjects, clashes and perspectives. Once more: in this situation of depoliticization, decontextualization and depersonalization, in this situation in which social-political subjects and their material conditions are massified and standardized, muted and deleted, a democratic, inclusive and participative process of justification is not necessary, nor the different epistemological-political subjects with their vindications, politicity, oppositions and clashes in order of both grounding a political theory and applying it to the social and institutional world. That is, actually, the reason why Rawls and Habermas put institutions in general and the rule of law in particular as basis, arena, dynamic and subject of validation and application of political justice into society, peripherizing civil society's political subjects and their clashes as marginal subjects, practices and movements.

Until this moment, we defined Rawls's and Habermas's liberal political theories as being based on an apolitical, depoliticized, decontextualized and depersonalized model of subject, context, practice and value for the foundation of a political theory for democracy and pluralism, which means, as a consequence, both a negative and unpolitical notion of pluralism and a massified and standardized concept of epistemological-political subject with no politicity, carnality and personalization. In this sense, first, the political theory is grounded on and forged from an unpolitical standpoint, an a-historical context, a depoliticized and depersonalized subject, and impartial and neutral values and practices as condition for objectivity, validity and justification; second, the political theory for democracy and pluralism silences about and deletes the practical linking, carnality and politicity of the epistemological-political subjects, erasing the differences, the clashes, the oppositions and the contradictions that constitute the Realpolitik as a context of the very political theory and social normativity; third, the unpoliticity, impersonality and decontextualization are the methodological-programmatic strategy for the foundation of a political theory and a binding notion of social normativity which are very political, very critical, from the idea that intersubjective interactions and consensus between plural subjects and, as a consequence, the critical, political and normative basis that allows intersubjectivity are possible only from the negation and delegitimation of current politicity, carnality and belongings. Now, permeating such an unpolitical theory, their depoliticized, depersonalized and decontextualized conditions, arenas, practices and subjects, is the difference and the opposition between publicpolitical and private which is absolutely central in terms of definition of what is the publicpolitical and, as a consequence, of what we can do or not as public-political subjects and in terms of public-political sphere and institutions, as what we cannot do or perform in terms of private sphere of the civil society, as private subjects. Here, therefore, the contraposition of politics versus unpolitical privatization defines, determines the construction of a liberal political theory for democracy and pluralism, for Western modernization as a whole.

Now, if an unpolitical and depoliticized pluralism is the condition for the foundation of a political theory and of a notion of social normativity for democracy, the reason is that liberal political theory assumes a strong and strict separation between public-political and private that is streamlined by the ideia that the private is the criterion from which the public-political is forged, based on and oriented. That is not Rawls's specificity, since it is the modern liberal political theory's fundamental theoretical-normative standpoint: individual rights establish an unpolitical and depoliticized, an impartial and neutral zone of individual and social life that politics cannot access and influence, because that zone is not political, not politicized. Rawls, of course, maintains such a liberal notion, so that in his theory of justice the individual rights are the basis from which the political and social rights are constructed and defined (cf.: Rawls, 2000b, pp. 335372) - Rawls's political justice as a pure political theory has as its groundwork the apolitical individual and its private rights, which means that corrective justice, on the one hand, is founded on them and, on the other, is determined by their apoliticity and privatization, leading to a great political limitation by the consolidation of an obscure and undetermined zone of civil society that is not political and, as a consequence, cannot be framed by politics. In the same way, Habermas's 
theory of modernity separates civil society in relation to social systems, conceiving of the first as a cultural, political and normative arena, streamlined by informal subjects, actions, values and dynamics, and the second as a very technical-logical, non-political and non-normative structure, arena and subject, self-referential, self-subsisting, autonomous and overlapped with politicalnormative subjects and praxis, and having an internal technical-logical proceduralism as basis of their constitution, legitimation and evolution (cf.: Habermas, 2012b, pp. 260-275). On the other hand, Habermas puts social systems in general and juridical-political institutions in particular inside the cultural, political and normative context represented and streamlined by civil society (cf.: Habermas, 2012a, pp. 588-591; Habermas, 2003b, pp. 83-84, p. 99). Now, in Habermas's sketch, we have an embracing cultural, political and normative context which contains and even subsumes an unpolitical, non-normative and technical-logical micro-context which is very private, self-referential, self-subsisting and depoliticized, a theoretical framework that, in Habermas's mind, signifies the fact that civil society is both the ontogenetic basis of the social systems and their principle of framing and control, because it is a normative sphere that allows and grounds social criticism and political emancipation from the centrality of the praxis. However, as Rawls's political theory, Habermas's political theory assumes a notion of privatization that he uses as the most basic principle and legacy of the process of Western modernization, so that, from this theoretical standpoint, politics and political-normative praxis are in the same place as such a private, technical-logical and depoliticized micro-context (see Habermas, 2003b, p. 25, p. 72, pp. 104-106; Habermas, 2002b, p. 501; Habermas, 1997, pp. 163) - in Rawls, the depoliticized sphere is given by individual rights; in Habermas, it is given by social systems (for example, the market). In the case of Habermas, it is important to mention that the social systems are private and depoliticized structures, arenas and subjects with no politicity, carnality and social linking, since he conceives of them as institutions with an impartial, neutral, formal and impersonal proceduralism as basis of their constitution, legitimation and evolution, which signifies that social systems are self-referential, self-subsisting, autonomous, closed and overlapped structures regarding civil society-notwithstanding the fact that they are inserted into civil society as a normative-political context. Both Rawls and Habermas, therefore, assume a contraposition between public-political and private that undermines the effectiveness of the political-normative praxis as basis and instrument of social criticism and political-cultural emancipation, as well as it weakens civil society's spontaneous social movements, citizen initiatives and cultural minorities that perform a kind of anti-systemic, anti-institutionalist and non-technical political praxis directed toward the confrontation and framing of this unpolitical, depoliticized and technical-logical zone constituted by liberal individual rights and technicallogical social systems.

For Rawls and Habermas, therefore, it is very clear that the correlation of unpolitical individual rights and technical-logical social systems is the theoretical-political standpoint that must be taken from the very beginning as the motto and the principle for the construction of a political theory for a current Western democratic society, which means that the notions of social criticism, emancipatory politics and social-political justice, if they are possible (and Rawls and Habermas do considerer they possible, of course), require the assumption of this apoliticity, neutrality, technicality and closure or privatization of individual rights and social systems as the condition for the justification of a public-political notion of praxis and justice. That is the reason, first, for the fact that a political theory for a democracy based on the correlation of pluralism and individual rights must be depoliticized, unpolitical, depersonalized and decontextualized, because only through the impartiality, neutrality, formalism and impersonality regarding the singularities, allowed by them, it is possible to achieve a socially binding political-normative consensus. Here, individual rights, conceived of from an unpolitical standpoint, demand the privatization of themselves, which is very interesting and also contradictory for a political-normative theory that intends to face the conflict around the right's effectiveness (publicly and privately!) - now, if the theoretical-political intention is to resolve the conflicts of integration and sociability, then it must start from them, not by their silencing, deletion and depoliticization. We said privatization of individual rights meaning with that the fact that political theory and social normativity are determined from the conditions and consequences (apoliticity, depoliticization, neutrality and impartiality) of this liberal understanding of the individual rights: by establishing a grey zone of foundation and action, a zero, pure and undeterminated zone of politics (with no class divisions, oppositions, conflicts and hegemonies), they do not allow a clear and political framing of what the individual sphere and subjects define as unpolitical, depoliticized and technical. In other words, it is the private sphere by privatization that defines what is politics and political and what is private, non-political, non-normative, technical, merely individual. Therefore, here, the 
consequence is very direct: the private defines, determines and frames the public-political from an apolitical standpoint, that is, from the correlation of meritocracy and technicality to politics, political institutions, political praxis and normative social vindications, which are based on, framed and oriented by apolitical meritocracy and technical-logical social systems. Publicpolitical sphere, institutions, practices, values and subjects become peripheral and basically submitted to the privatization of civil society, its subjects, practices and values, which means that political arrangements, dynamics and relations to civil society are always indirect, in the sense that they cannot politicize both individual rights and the property (social systems) which is associated to them (see Habermas, 2003b, pp. 104-105, pp. 247-248; Habermas, 2002b, pp. 501507). In this case, Rawls's liberal political theory conducts very strongly to depoliticization and privatization of civil society, its subjects, institutions, political clashes and normative vindications, the same as a model of minimal politics that cannot solve the problems of social integration, because it is limited and defined by the private, unpolitical, depoliticized, depersonalized and basically individualized civil society - meritocracy with a few social rights publicly granted is the only way and remedy for privatization, legitimized by privatization, which means that social activities performed by an association of free and equal citizens for mutual benefit over time is subsumed into the privatization, depoliticization and individualization of civil society's institutions, enterprises and subjects, associated always with unpolitical and depoliticized individual rights (see Rawls, 2003, §02, pp. 06-11).

Second, the privatization and depoliticization of civil society occurs due to the understanding of the social systems as private and unpolitical structures, arenas and subjects constituted, legitimized and streamlined from a technical-logical standpoint which is correlatively internal, autonomous, closed, self-referential, self-subsisting and overlapped with civil society, as non-normative and non-political in terms of political framing, justification and intervention institutionally conducted. Indeed, for Habermas, despite the social systems' link to civil society as a normative, cultural and political sphere (cf.: Habermas, 2003b, pp. 186-187), they have a technical-logical constitution, legitimation and evolution which depoliticizes them, so that they acquire an instrumental sense, structuration and dynamic that cannot be understood, framed and oriented - not even changed - by a direct, participative and inclusive democratic politicalnormative praxis from civil society to institutions (cf.: Habermas, 2002b, pp. 496-501; Habermas, 2003 b, pp. $21-25$, p. 72 , pp. 104-106, pp. 147-148). Private, unpolitical, non-normative and technical-logical social systems have an internal and very closed functioning, managing and programming that is centralized, monopolized and defined by institutional elites and technicians firstly and basically. Here, democracy does not play any role, as it is not the institutional core and orientation in terms of managing, functioning and programming, in terms of institutional link and influence, but only institutions' technicality, self-referentiality and autonomy. Now, the difference between public-political and private and unpolitical, between civil society's political-normative praxis and civil society's unpolitical, private and technical-logical social systems, leads, despite Habermas's intention, to the weakening of the political praxis and of the social normativity as instances for criticism, control, framing and changing of the technical-logical social systems, since it has instituted a very private and unpolitical zone of civil society-the technical-logical, non-political and non-normative social systems, self-referential, self-subsisting, autonomous, closed and overlapped to politics and social normativity - that cannot be explicated, framed, intervened in and changed by political praxis performed both for civil society's informal subjects and political-juridical institutions' formal subjects. What remains for a corrective justice assumed and performed for political praxis and juridical-political institutions are indirect politicalinstitutional interventions that do not touch or change the private and unpolitical sense, constitution and evolution of social systems, which means that politics can at most minimize the social effects of economic system and political parties' technocracy, but never politicize them integrally. Here, civil society's political-normative arenas, subjects, struggles and values are peripheral to the privatization of social systems and individual rights - and it is not a coincidence that both Rawls and Habermas deny a direct, participative and inclusive democratic political praxis that is generated from civil society to institutions and puts down the institutions' technicallogical, unpolitical and non-normative constitution, legitimation and evolution (cf.: Rawls, 2000a, $\S \S 53-59$, pp. 388-434; Habermas, 2003b, pp. 147-148; Habermas, 2002b, p. 506-507). Institutions' apoliticity, self-referentiality and autonomy must be respected for politics; institutions' internal elites and technicians are the very basic subjects of social systems' selfauthorized legal staffs, so that social movements, citizen initiatives and political-cultural minorities can ground and perform an anti-systemic, anti-institutionalist and anti-technicist political-normative praxis until the social systems' stairs; from here, it is the very social systems' 
authorities from a technical-logical standpoint which is very internal and self-subsisting to institutions that have centrality in terms of programming, functioning and managing of these institutions.

Now, the political-normative consequences of the privatization, depoliticization and technicization of both individual rights and social systems are very serious and lead to the apoliticity, depoliticization and privatization of the very central part of civil society, that is, the social and public institutions and power relations of the social-political subjects. Indeed, Rawls and Habermas conceive of a very unpolitical, depoliticized, privatized and, therefore, technicallogical part of civil society that involves exactly the most nucleus of it, that which is the center of the social-political clashes, disputes and hegemonies. First of all, the difference between publicpolitical and the private, with the assumption of the unpolitical pluralism and the privatization of the individual rights constructs a very impenetrable barrier between politics and civil society. What is part of civil society is unpolitical, individualized, depoliticized, because privatized. And civil society is defined by all as what is typical of individual rights, like comprehensive doctrines and economic activities. Now, what does define politics and political institutions? Rawls said: the basic structure of society, which must be ordered and directed by a political conception of justice. On the other hand, this political conception of justice is based on and framed by the apolitical and private individual rights which, as we said above, establish a very particularized and depoliticized sphere of civil society which is not political, but privatized. Now, how is it possible to conciliate a political theory directed toward the basic structure of society and a notion of individual rights that privatizes this basic structure of society? How is a political theory for the basic structure of society from an unpolitical, depoliticized and privatized basis, procedure and subject possible? That is not possible at all and, as a consequence, politics and political institutions become victims of the privatization of the subjects, their individual rights and, moreover, the civil society's practices, values and institutions based and dependent on privatized and unpolitical individual rights - as is the case of the economic system. In the same sense, Habermas's technicization and depoliticization of modern social systems (capitalist market, State, political parties, courts) make them technical-logical institutions whose basic condition and characteristic is their privatization, apoliticity, closure and self-referentiality, which make them autonomous, overlapped and selfsubsistent regarding politics and social normativity. Here again, an anti-systemic praxis by noninstitutionalized subjects of civil society is weakened and in the end delegitimized by institutional technicality, closure and depoliticization. As a consequence, it is necessary to overcome the separation between public-political and the unpolitical private, between civil society and social systems, between informal politics and subjects and formal politics and subjects. Indeed, a model of radical politics in the age of the correlation of strong institutionalism, systemic selfreferentiality and technicality of the power, as an alternative to political-institutional conservatism, must assume a comprehensive politicization of the social systems, overcoming the separation between civil society and social systems from an anti-systemic, anti-institutionalist and non-technical praxis from the marginalized and by them.

\section{THE SOCIAL-POLITICAL CORE AND ROLE OF INSTITUTIONALIZED AND UNIVERSALIST RELIGIONS: THE PRIVATE SPHERE AS BASIS OF THE POLITICAL - ON ANOTHER CONSEQUENCE OF THE SEPARATION BETWEEN PUBLIC-POLITICAL AND PRIVATE}

We said above that liberal political theories depoliticize civil society by privatizing individual rights and social systems, by correlating them (a) with the apolitical meritocracy and (b) the technical-logical, self-referential, self-subsisting, autonomous, closed and overlapped apolitical institutions of civil society (such as the market, for example). In the same way, the foundation of a political theory and of a notion of social normativity for a Western democratic, pluralist and complex society points to the necessity of an unpolitical understanding of pluralism and to the weakening of politics and political institutions as basis and instrument of social constitution, legitimation and evolution, since Western democratic, pluralist and complex societies are characterized (a) by the privatization, anonimization and individualization of the epistemological-political subjects, (b) by the existence of an opposed myriad of comprehensive doctrines each one competing with another (a negative sense of pluralism, therefore); and (c) by the decentralization of society, which becomes constituted and streamlined by very particularized, autonomous and private social systems, each one of them centralizing and monopolizing (and, 
therefore, depoliticizing, privatizing) the social field that it represents. More: in this situation of anonymity-individualization of the epistemological-political subjects, conflictive pluralism and privatization-depoliticization of the social systems, the foundation of the political theory, its contexts, actions and practical linking become less radical and, in truth, basically limited by a notion of civil society that is clearly unpolitical, depoliticized and privatized. As a consequence, this is not a coincidence that in the construction and foundation of the liberal political theories the unpolitical individual rights, the unpolitical pluralism and the privatized and technical-logical social systems ground and promote a kind of impartial, neutral, formal and impersonal proceduralism which establishes at most a model of minimal, indirect and institutionalist politics that is framed and directed by apoliticity, depoliticization, technicization and privatization of individuals rights, pluralism and social systems. That means that politics cannot intervene directly and based on a notion of social normativity in the privatized and depoliticized civil society in terms of questioning, problematizing and changing status quo which is dependent on the very constitution, legitimation and evolution of social systems, which is streamlined and based on the privatization and apoliticity of civil society - since the more important characteristic of the status quo in conservatism is its depoliticization and privatization, as a matter of/for meritocracy into the apolitical and technical-logical sphere of production and market. In the same dynamic, liberal political theories demand a methodological-programmatic context, subject, practice and value which is apolitical and depoliticized, decontextualized and depersonalized as condition for the foundation of a political theory for such a model of Western democratic, pluralist, individualized and complex society: here, an apolitical, depoliticized, depersonalized and decontextualized arena, subject, practice, value and starting point is the only alternative for liberalism because it assumes the privatization and the depoliticization of civil society, deleting social-political classes, clashes and dynamics that define the complete politicization of society, its subjects, struggles and institutions.

Finally, liberal political theories act from this apolitical and depoliticized basis because they strongly separate the public-political from the private-apolitical, by conceiving, as we said above, from an unpolitical standpoint the constitution and the affirmation of the individual rights, pluralism and mainly the functioning, programming and linking of the social systems or institutions of civil society. In this sense, civil society, its subjects, institutions, practices and values appear with a very large dose of apoliticity and depoliticization, which means the consolidation of a zone of indefinition in which it is not clear what is political and what politics can effectively do. In truth, civil society, by the separation between public-political versus private-apolitical, becomes depoliticized and privatized by the apoliticity, depersonalization and decontextualization that permeate and surround the constitution of and the correlation among social systems, individual rights and pluralism. Now, in the moment that they establish spheres, subjects, practices and values that are not political and normative, but just individualized, technicized and privatized (as a non-public, non-normative concern, subjects, practice, value and institution), the civil society becomes apolitical, depoliticized and privatized, which means that political theory loses its focus, destination and subject, as (and insofar as) it is framed by the apolitical civil society. Here, the privatization of civil society's institutions, subjects, practices and values become central regarding public-political and determines a minimal and indirect politics that cannot be effectively emancipatory, because it is submitted to and weakened by the civil society's apoliticity, depoliticization and privatization. Once more: liberal political theories put the private-apolitical as basis of the political, which means that a depoliticized, apolitical, decontextualized, depersonalized and private zone, subject, practice and value have the absolute priority and centrality regarding what is public-political and, therefore, by being public-political, can be framed, criticized and changed.

Now, in this section, we want to think on another very important aspect of this separation and opposition between the public-political and the private-apolitical that pervades and streamlines the constitution, the legitimation and the evolution of our current Western societies (and even beyond). Here again, we can perceive the fact that the private-apolitical is used to frame, constitute and orientate the public-political linking and statements of civil society's institutions, by deleting and silencing the differences, their oppositions, struggles and contradictions as the very basis of the politics, of the public sphere. Here, therefore, private institutions of civil society, by affirming an essentialist and naturalized basis and the correlation between strong institutionalism, strong objectivity and political fundamentalism, deny the very basis of society and politics, which is the tense, conflictive and irreducible differences. The case of institutionalized and universalist religions and many cultural traditions (as nationalism and racism) has many similarities with political liberalism, principally in the fact that they 
depoliticize the public sphere from the affirmation and imposition of a standardized and depersonalized anthropological-ontological and epistemological-political paradigm based on essentialist and naturalized foundations, based on biology and traditional religion-culture, that undermines, silences and even denies the differences as alternative and opposed epistemologicalpolitical subjects, with their own practices, values and worldviews. Here, the similarity between political liberalism and institutionalized and universalist religions is in the fact that, if liberalism standardizes and massifies the individuals and social-cultural groups by denying the differences in their carnality, politicity and social-cultural linking-belongings as starting point, dynamic and final point of the political-normative foundation, pointing to an impartial, neutral, formal and impersonal proceduralism which correlatively conceives of a pure model of social subject and the negative sense of pluralism, which means the deletion of the differences, oppositions and mutual conflicts of the praxis of foundation; institutionalized and universalist religions put an essentialist and naturalized basis - which is a-historical, universalist, unidimensional and also massifying - as groundwork, value and instrument from which a civil society's institution performs a public-political core and role from privatism to politicization, affirming the privatism (standardization) as a condition of politics (differences) (see: Danner, Bavaresco \& Danner, 2017a, pp. 510-542; Danner, Bavaresco \& Danner, 2017b, p. 53-91). First of all: what is an institutionalized and universalist religion? It is a kind of religion that constitutes, legitimizes and streamlines itself from the centralization, monopolization and privatization of the grounding of the specific creed for a very closed, self-referential and self-subsisting community of religious authorities and/as theologians. In this sense, an institutional religion is a kind of social system with technical-logical sense, dynamic and constitution, that is, a private community that monopolizes and centralizes (and, therefore, that privatizes-depoliticizes, at least in a high sense) the valid interpretation, legitimation and social imposition of the creed. As a consequence, here, only the religious institutions and their theological and self-authorized community from a very internal proceduralism, methodology and values have the ability and legitimacy to publicly constitute, ground and streamline the specific creed assumed, centralized and monopolized by this religious community. In the same dynamic, this institutionalized religion, based on essentialist and naturalized foundations, is universalist in the sense that its codes, practices, values, worldview and authorities assume that all individuals and social-cultural groups constitute one same family which must be united, framed and guided by this religious institution, which conducts it to a missionary movement toward humankind as a whole, standardizing and massifying the differences from that same ontogenetic basis which is more primary than the very differences, their condition of justification, criticism and living (and even salvation) (see Danner, 2016a, pp. 174-196; Danner, 2016b, p. 31-71; Corbì, 2012, pp. 251-254; Robles, 2012, pp. 185192; Montealegre, 2012, pp. 135-139). Second: how is the basis of the constitution, legitimation and social-political linking of an institutionalized and universalist religion? And what does the institutional centralization, monopolization and privatization of the creed allow? Now, the basis of the constitution, legitimation, dynamic and social-political linking of an institutionalized and universalist religion is the correlation of strong institutionalism, strong anthropologicalontological, social-cultural and epistemological-moral objectivity and political-moral fundamentalism, in the sense that an institutionalized and universalist religion has, as condition of its centralization, monopolization and privatization of the creed, to assume that it is based on essentialist and naturalized foundations which, by their a-historical sense and constitution, can only be interpreted, legitimized and streamlined from a very institutionalist community with very institutionalist instruments, practices and values, something that common sense and common people do not allow or have not capability of performing with effectiveness (see Danner, 2017c, pp. 11-31; Rorty, 2010, pp. 12-44).

Now, strong institutionalism means exactly what was said above, namely the fact that an institutionalized and universalist religion centralizes, monopolizes and privatizes the creed, becoming the only basis, subject, procedure and arbiter regarding the creed's constitution, legitimation and social-cultural foment. That originates a vertical and direct-from top to bottom-institutional framing, orienting and judging of common sense and common people, of pluralism as a whole from such kind of strong institutionalism, in that religious institutions become a super-subject that, from its internal values, practices and self-authorized subjects, frames, comprehends and orients the public-political from within and vertically. In the same sense, strong anthropological-ontological, social-cultural and epistemological-moral objectivity means that, for an institutionalized and universalist religion, only an essentialist and naturalized basis which is a-historical and totally universalist - a model of human nature in individual, cultural and social terms that is standardized throughout all of the pluralism-can provide a 
normative and critic paradigm for current life, for the framing, criticism and orientation of the plurality of subjects, values and practices over time. Here, such a model of strong objectivity is the basic matter that is centralized, monopolized and privatized by an institutionalized and universalist religion, in that its foundation, constitution and streamlining are possible only by an institution and from institutionalization, from privatization, at least in a very strong way. Now, strong institutionalism, by being based on strong objectivity, leads to political-moral fundamentalism as the public-political core and role of institutionalized and universalist religions. By the concept of political-moral fundamentalism we understand the application of the privatized, a-historical, apolitical and standardized essentialist and naturalized basis of a singular and self-referential institution into society as a whole, which means the framing, the criticism and the orientation of the differences from a unidimensional paradigm and action-here, the differences are not seen nor affirmed as in the same position than the institution's subjects and believers, as partners of a dialogical interaction, but as fallen subjects, practices and values which must be framed, oriented and changed by strong institutionalism from strong objectivity- the differences are seen and thematized for an unpolitical (because essentialist, naturalized and ahistorical) basis that leads to their depoliticization as alternative epistemological-moral subjects, values and practices.

The correlation of strong institutionalism, strong objectivity and political-moral fundamentalism of institutionalized and universalist religions concerning the public-political sphere and the differences is very unpolitical and privatized, because a-historical, essentialist and naturalized, as we said, which leads to the non-recognition of the differences in their irreducibility, in their singularity, differences' irreducibility such as demands paradigmatic, political and moral openness. The strong institutionalism based on essentialist and naturalized foundations and imposing a kind of institutional political-moral fundamentalism is privatized, unpolitical and standardizing-massifying because it does not recognize the differences as publicpolitical subjects, spheres, practices and values, as it does not understand itself as a publicpolitical institution, subject, value and practice - or associates public-political with a privatized essentialist and naturalized basis, and not with differences. How can strong institutionalism based on essentialist and naturalized foundations be apolitical, depoliticized? By the fact that it denies politics as tension, interaction and struggle between the differences, the politics as a praxis, arena and value that, having not an essentialist and naturalized basis which is a-historical and highly universalist, require interaction, conflict, hard discussion and disputes between alternative and opposed subjects, practices and values. In other words, the correlation of strong institutionalism, strong objectivity and political-moral fundamentalism is apolitical, depoliticized-depoliticizing because it does not recognize the differences as the starting point and the dynamic of the publicpolitical, which would not be public-political without the differences in their politicity, carnality, personalization and social-cultural linking. The same as it occurs with political liberalism based on apolitical individual rights, unpolitical pluralism and technical-logical civil society's institutions, the institutionalized and universalist religions, since they affirm the correlation between strong institutionalism, strong objectivity and political-moral fundamentalism, depoliticize the public-political sphere by deleting the differences as starting point, ground, dynamic and subject of the foundation, establishing as counterpoint a very standardized, massified and univocal notion of subject, value and practice which are not political, but private, a model of a particular worldview that is confused to and affirmed as the common ground and the only subject and way for validity, objectivity and intersubjectivity. In this case, the understanding, foundation and orientation of the public-political sphere become the understanding, foundation and orientation of a civil society's private institution that is associated with the plurality of differences as a whole. Here, politics as historical, personalized and plural competing subjects, values and practices is substituted by theology in its massified, totalizing and depoliticizing notions of human being and human community, likewise the conflictive interaction and dispute about hegemony and justification are substituted with fundamentalism, and the differences are replaced with institution's self-authorized legal staffs.

Institutionalized and universalist religions put their particular essentialist and naturalized basis as core and role of the social integration, which means the erasing of politics of the public sphere and, as a consequence, the transformation of the public-political sphere in a private, apolitical, depoliticized and unidimensional sphere. The differences as radical alterity are denied by these unidimensional and totalizing imposition of the institutional creed on society as a whole, like nowadays social-political subjects are substituted with institutional self-authorized authorities which, from the use of theology based on essentialist and naturalized foundations, replace an anarchic, open and very political interaction and dispute for hegemony-since the 
differences weaken strong objectivity and reject political-moral fundamentalism, requiring as counterpoint epistemological-political openness and (conflictive) interaction as motto and dynamic of the public-political agreements-by institutions' internal, privatized, depoliticized and dogmatic authorities, values, practices and ways. As a consequence, they massify and standardize the social-political sphere and the differences from the affirmation and imposition of a univocal notion of paradigm, subject, action and value which is ontogenetically primordial in relation to the differences themselves. Here again, as in contemporary liberal political theories, the social-political sphere, the pluralism-differences and the praxis are depersonalized, decontextualized and, as a consequence, depoliticized, because the correlation of strong institutionalism, strong objectivity and political-moral fundamentalism massifies and standardizes - therefore, it depoliticizes - the multiplicity of subjects, values and practices, the basic disagreement and differentiation that require more epistemological-political-institutional openness, interaction, politicization. From an essentialist and naturalized basis, all is seen, affirmed and framed from a univocal standpoint which is a-historical and standardizing; in the same sense, from political-moral fundamentalism, politics and the multiple social subjects are not necessary, since one single and dogmatic-messianic generic subject, with an a-historical constitution, with no carnality, politicity and linking, can ground and streamline the very social, political and normative basis of current life. This massification-standardization-apoliticity of the differences, of the social-political subjects, based on the correlation of the a-historicity of the approach and an institutional essentialist and naturalized basis imposed and performed in terms of political-moral fundamentalism in the public-political sphere can be seen in the XIV Synod of Bishops' Final Rapport regarding family, gender and sexuality in the $21^{\text {st }}$ century both in the Catholic Church and in contemporary world:

Today, a very important cultural challenge is posed by "gender" ideology which denies the differences and reciprocity in nature of a man and a woman and envisages a society without gender differences, thereby removing the anthropological foundation of the family. This ideology leads to educational programmes and legislative guidelines which promote a personal identity and emotional intimacy radically separated from the biological difference between male and female. Consequently, human identity becomes the choice of the individual, which can also change over time. According to our faith, the differences between the sexes bears in itself the image and likeness of God (Gen 1: 26-27) (Synod of Bishops, $2015, \S 28)$.

An institutionalized and universalist religion, based on essentialist and naturalized foundations, as highly self-referential and self-subsisting regarding society and differences, has as its central dynamic and purpose universalism, as starting point and ending point for the constitution, legitimation, framing and orientation of the differences. First of all, an institutionalized and universalist religion intends to perform a messianic and salvific crusade against the degenerated pluralism and anti-natural (or anti-essentialist) differences. It is from this correlation of strong objectivity (essentialist and naturalized foundations) and universalism, strong objectivity as standardized, unidimensional and massified universalism, that a religion institution constitutes itself and publicly performs its practices and vindications, which means, again, that it frames the differences from the deletion and negation of their singularities, which cannot be assumed, comprehended and framed from outside the differences, outside each singular subject. Here, as we said above, politics is substituted by theology; the plurality of the subjects is depersonalized and decontextualized, by massification, by the understanding of them from an ahistorical principle, so that an institutional self-authorized subject can act and speak in name of this generic, formal and apolitical subject which lost its singularity, carnality and differentiation; and, finally, conflictive and constructive interaction can be replaced by the institution's vertical imposition of political-moral fundamentalism. As a consequence, from the privatization and depoliticization of the public sphere, as from the depersonalization and deletion of the differences in their singularity, carnality, linking and politicity, strong institutionalism can, based on essentialist and naturalized foundations, become the central - but apolitical, depoliticized, dogmatic, technical-logical and privatized-subject, arena, practice and value of the societalcultural-institutional constitution, legitimation and evolution, peripherizing the differences and, therefore, depoliticizing their condition, praxis and values. Here, there is no longer interaction and dispute, but a blind and vertical institutional fundamentalist practice, framing and comprehension of society and differences (see Collins, 2006; Vattimo, 2004).

In this sense, the correlation of strong institutionalism, strong objectivity and politicalmoral fundamentalism, by its characteristics of a-historicity, depersonalization, depoliticization 
and decontextualization, makes the constitution, the legitimation and the social imposition of the creed blind and insensible regarding the particularities and singularities of the differences, a condition which can only be affirmed and assumed in the moment that institutions, their authorities, values, practices and even believers are conscious and open to the carnality, personalization and politicity of the differences. It means mainly the necessity of politicization of the institutional creed, authorities, practices and values, in order to become enlightened about the public-political consequences, roots, core and role of a religious institution. Indeed, the institutional privatization and depoliticization are the most basic principles and consequences of strong institutionalism, which means that an institution-political, economic and religious-becomes self-referential, self-subsisting, autonomous and overlapped concerning political praxis and social normativity, concerning social subjects, but, on the other hand, it uses such a privatized and unpolitical basis for framing, judging and orienting a public-political condition allowed by the differences' plurality of subjects, values and practices. Now, there is a great depoliticization here due to the fact that a standardized and massified institutional basis, founded on the intersection of apoliticity-privatization-technicality and a-historical essentialist and naturalized principles, depersonalizes, decontextualizes and, therefore, depoliticizes the public-political sphere and the differences as public-political spheres, subjects, practices, values and relations, by imposing vertically an unpolitical, a-historical, depersonalized and decontextualized paradigm which will frame, judge and guide political-normative situations, the relations, struggles and contradictions of the differences as a whole from a privatized, impersonal and decontextualized standpoint. As in the case of contemporary political liberalism, how is it possible that a standardized-massified unpolitical, depersonalized and decontextualized paradigm imposed vertically and from private sphere on the public-political sphere assume the differences' politicity, tensions, struggles and contradictions? The only result of a vertical and massified institutional comprehension, framing and orienting of the differences is the blindness, the insensibility and the deletion of the differences in their carnality, politicity, personalization and contextualization - the only condition, therefore, is the unpoliticity of the public sphere, that is, the colonization of politics by the private-apolitical, which means and leads to the erasing of the differences and the consequent weakening of the public, political, cultural and institutional learning processes.

It is interesting, here, to mention the fact that the colonization of the public-political by the private sphere is an important concern for many of current institutionalized and universalist religions. Indeed, if we observe Pope Francis' institutional, social and political statements, we will perceive an attempt to rethink the Catholic Church's theological constitution and socialpolitical linking from the recognition that a standardized-massified-depersonalized institutional constitution, legitimation and public-political role is not possible at all in the time of the differences, which means the necessity of institutional moderation and weakening, as of institutional discernment, love, charity and sensibility with the differences and existential singularities in terms of grounding and, mostly, of application of the private creed into the social, cultural and political sphere. For Pope Francis, therefore, the recognition of the problem constituted by the correlation of strong institutionalism, strong objectivity and political-moral fundamentalism in terms of structuration of institutionalized and universalist religions is the central epistemological-political-institutional key for the institutional criticism, reconstruction and public-political linking, in order to avoid institutional apoliticity and technicality. In his very explosive encyclical Amoris Laetitia, we can see this correlation of strong institutionalism, strong objectivity and political-moral fundamentalism in terms of constitution and application of the institutional creed as the great and decisive challenge for Catholic Church in the $21^{\text {st }}$ century, namely:

For this reason, a pastor cannot feel that it is enough simply to apply moral laws to those living in "irregular" situations, as if they were stones to throw at people's lives. This would bespeak the closed heart of one used to hiding behind the Church's teachings, sitting on the chair of Moses and judging at times with superiority and superficiality difficult cases and wounded families (Pope Francis, 2016, §305, p. 236).

In other words, an immoderate and purely technical political-moral fundamentalism based on strong objectivity constituted, legitimized and imposed by and in terms of strong institutionalism is not possible. Such a kind of institutional dynamic, foundation and socialpolitical linking leads directly to the depoliticization and deletion of the differences' singularities, as of nowadays conditions regarding practices, values, tensions and struggles between opposed social, political and cultural subjects. There is not a pure, direct and technical foundation and 
application of private values for a self-referential and self-subsistent apolitical institution into the social, regarding the differences. Institutional constitution, legitimation and social-political linking are political-normative, because they are not and do not involve the grounding of abstract, impartial, neutral and formal rules, but exactly the very understanding, constitution and orienting of social life, of plurality, of the differences. This is the sense of the politicity, carnality and linking both of institutions and of social-political subjects, which means the non-sense of the privatization assumed by liberal political theories and institutionalized and universalist religions - in the same sense, in the case of Catholic Church, this is the very richness of Pope Francis' praxis of institutional renewal and social-political linking. As he said, "No one can be condemned for ever, because that is not the logic of the Gospel! Here I am not speaking only of the divorced and remarried, but of everyone, in whatever situation they find themselves" (Pope Francis, 2016, §297, p. 226). As Axel Honneth recognizes and affirms emphatically, the foundation and the application of practices and values are not technical, apolitical and nonnormative exercises of impartial, neutral, formal and impersonal institutions, subjects and processes, but very political-normative ones, with carnality, politicity and linking to practical subjects, actions, values and worldviews. In this sense, the recognition is prior in ontogenetic terms to cognition, which means that the theoretical foundation and the practical-political application - very intrinsic and dependent on each other-are always political-normative (see Honneth, 2007, p. 61-65; Honneth, 2002, p. 258). This also means that the negation of the recognition of the differences from an a-historical, apolitical, privatized, technical, depersonalized and decontextualized paradigmatic basis is always political-normative, because our understanding, framing and orientation of public-political subjects, issues, values and practices are, of course and primarily, political-normative ones. And here is the importance of an institutional authority as Pope Francis, who is one of the most central world leaders, ruling one of the most central world institutions which centralizes, legitimizes and streamlines one of the more important worldviews, in the moment that he proposes the institutional moderation, weakening and openness of the correlation foundation-application of the creed regarding the differences in their carnality, politicity, linking and singularity (see Habermas \& Ratzinger, 2007, pp. 23-90; Catroga, 2006, pp. 457-459; Marramao, 1997, pp. 38-44; Marramao, 1995, pp. 295-331).

Now, Pope Francis's theological posture is also a political posture, and it directly and emphatically exemplifies our argument that there is no separation and opposition between the public-political and the private-apolitical. That separation-opposition does not work for our current problems, challenges and potentialities, because both the separation-opposition and the hegemony-colonization of the private-apolitical in relation to the public-political (a) depoliticizes the public-political sphere, subjects, struggles, practices and values, imposing the primacy of the technical, depersonalized and decontextualized subjects, institutions, values and practices of civil society, as if civil society were a very apolitical, technical, private and peaceful space with no political-normative constitution and dynamics; (b) deletes and silences the social struggles, contradictions, tensions and personalization of the social-political subjects, by depoliticizing and technicizing the constitution of the civil society and of politics, as the relation between them-here, social evolution appears as a movement-dynamic with no politicity, carnality, personalization and contextualization, a very controlled scientific-lab experiment with a technical-logical way, practices, methods and actions; and (c) standardizes and massifies the differences and the oppositions from both a depersonalized and decontextualized model of subject and an essentialist and naturalized basis which erases the differences as ontogenetic ground and dynamic from which the public-political is forged and defined over time. In this sense, an apolitical and very privatized sphere is constituted and streamlined by apolitical subjects with a technical-logical constitution, legitimation and performance, with no structural sense and range, which means, as a consequence, that the comprehension, grounding and changing of civil society is technical, apolitical and depersonalized; likewise, the apoliticitytechnicality-depersonalization of civil society imposes an apolitical iron prison and way to politics and public institutions, in the sense that they are framed by civil society's technicalityapoliticity and minimized and peripherized by civil society's privatism, closure and selfreferentiality. The separation between public-political and the private-apolitical leads, therefore, to the technicization of both civil society and politics, but it also leads to the apolitical-technical colonization of the public-political sphere by a kind of apolitical and instrumental action, value and subject. As was said above, contemporary times, characterized by the colonization of the public-political by the private-apolitical, directly and pungently require the radical politicization of civil society, its subjects, struggles and institutions, which means firstly and basically the overcoming of the separation between public-political and private-apolitical (and the consequent 
overcoming of the colonization of politics by apolitical-depoliticized institutions of civil society) assumed by liberal political theories based on a technical-logical understanding of social systems, by the depoliticization of social subjects and by the privatization of meritocracy, as potentialized by institutionalized and universalist religions based on essentialist and naturalized foundations in their treatment of the differences as the public-political condition of societal-institutional constitution, legitimation, evolution and grounding.

\section{A POLITICAL THEORY OF DEMOCRACY BEYOND THE SEPARATION BETWEEN PUBLIC-POLITICAL AND PRIVATE: ON THE POLITICIZATION OF CIVIL SOCIETY}

Now, as we said above, the most impactful and central challenge for nowadays Western democratic societies - and even beyond - is exactly the colonization and technicization of the public-political by a conservative notion of civil society's apoliticity, depoliticization, decontextualization and depersonalization, which leads to the reduction of politics to a technical action submitted to the self-referentiality, self-subsistence, autonomy and overlapping constitution and functioning of the social systems. It leads also to the anonimization, individualization and, therefore, depoliticization of the social-political classes, which lose their structural constitution and dimension, which means that institutionalism is the only object and subject of the political theories, and no more the social classes, the living subjects of praxis. Finally, institutionalized and universalist religions contribute to the colonization of the publicpolitical by the private-apolitical since they use private essentialist and naturalized basis to frame, criticize and orientate the differences as public-political spheres, subjects, values and practices, minimizing or even erasing the centrality of the differences for both institutional constitution, legitimation and evolution and social-political-cultural dynamics and foundations. As a consequence of these theoretical-practical assumptions, we can see in nowadays societies and globalization a set of problematic values and practices which powerfully harm the centrality of politics, of the political praxis, of the differences, and the social, political, cultural, economic and religious stability of these societies and globalization: the autonomization, self-referentiality, selfsubsistence and depoliticization of social systems; the weakening and the submission of political praxis and political institutions to technical-logical, non-political and non-normative institutions; strong institutionalism as basis of the constitution, legitimation and social performance of both social systems and political-juridical institutions, in that it substitutes the praxis and the social classes, with their confrontations, oppositions and hegemonies, by the technical-logical and very internal managing, programming and functioning of the institutions centralized and monopolized by institutional authorities and technicians; and, finally, the highly standardized and massified public-political linking and posture of many institutionalized and universalist religions that, by the intersection and mutual support among strong institutionalism, strong anthropologicalontological objectivity and political-moral fundamentalism, deletes and minimizes the core and the role of the differences in the public-political sphere, trying to push and put them into the private and apolitical sphere and conceiving of them as privatized, depoliticized, depersonalized and decontextualized subjects, struggles, values and practices. Here, in the strong institutionalism based on and promoting the technicality, depoliticization and privatism, the social-political subjects are massified and standardized, having their personalization, contextualization and politicization erased, deleted and denied by institutions and by political-normative theories that assume institutions as object and subject of their foundation and social-political application and linking. In the three cases, the differentiation and the opposition between the public-political and the private-apolitical permeates and legitimizes the increasing depoliticization and autonomization of social systems, as the weakening and harming of the public-political sphere, praxis, struggles, subjects and institutions. Now, it is the time of overcoming this nefarious theoretical-political basis of political liberalism and institutionalized and universalist religions, a point that denies political praxis, social classes, the differences and the struggles as basis of societal-institutional framing, criticism and changing, establishing strong institutionalism (a technical-logical, non-political and non-normative model of institution, social-political subject, practice and value) as the central and definitive arena, dynamic and subject of society, of criticism and emancipation; and establishing also a model of depersonalized, decontextualized and massified private and undetermined subject that has no politicity, carnality and belonging, which consolidates the technical-logical, self-referential and self-subsisting institutionalism as societal basis, the way and the final result of political theory. 
We identify two problematic characteristics-practices of contemporary liberal political theories and institutionalized and universalist religions which are the consequence of the radical separation between public-political sphere, subjects, praxis and values and private-apolitical sphere, subjects, practices and values. First of them, the negative sense of pluralism, since, if it is radically affirmed according to liberalism and institutionalized and universalist religions, it leads to the impossibility of a political agreement and of the politicization of civil society. As a consequence, it must be weakened and even silenced, and that signifies the necessity of an impartial, neutral, formal and impersonal proceduralism as arena and dynamic of the publicpolitical constitution and legitimation, as the centrality of a depersonalized, depoliticizedapolitical and decontextualized notion of subject which reduces the plurality to one single, massified and standardized model of subject of action and foundation-as a consequence, civil society, in its apoliticity, massification, standardization and privatism, is placed as the basis of the public-political, so that, in this case, pluralism cannot be taken seriously and radically in terms of a political theory. Here, a depoliticized, undefined-undetermined and decontextualized principle, practice, arena and subject become the basis of the foundation, which means ignoring politics and the politicity-carnality of the public-political sphere, of the praxis, of the real subjects. In this sense, both liberal political theories and institutionalized and universalist religions do not effectively and radically assume the differences in their tensions, contradictions, oppositions, practices, values and struggles as the basis and the positive tension for the construction of a more open, egalitarian and inclusive-participative society and its socially binding institutions, codes and practices. Indeed, with the correlation of an impartial, neutral, formal and impersonal proceduralism as method and practice of the public-political foundation and of a depersonalized, decontextualized, a-historical and depoliticized model of subject of foundation, both liberal political theories and institutionalized and universalist religions standardize and massify the context, the subjects and the struggles in terms of comprehension and foundation of the publicpolitical: a single universal (a-historical, apolitical-depoliticized, decontextualized, pure) subject is sufficient in liberalism; a single universal (a-historical, essentialist, apolitical) institution is sufficient for institutionalized and universalist religions. The second is that for both liberal political theories and institutionalized and universalist religions a pure notion of social normativity is sufficient for the foundation of the political, in the sense that from an a-historical, decontextualized, depoliticized and depersonalized arena, procedure and subject of the foundation is possible to achieve the objectivity-intersubjectivity, the validation and justification of the public-political and its institutions, codes and practices. A pure notion of social normativity signifies that the socially and politically binding practices, values, subjects and institutions are constructed from the overlapping and silencing regarding practical contexts and the carnality and politicity of the social classes, with their differentiations, oppositions, projects of hegemony and struggles. Indeed, in the original position and discourse circle we do not know about political belongings or we silence and erase class struggles, contrapositions, hegemonies and belongings, we also delete the differences in their effectiveness, carnality and politicity, as if they were not a fact of social-political-cultural life, as if they were always a bad thing which must be denied, erased from political theory. In this sense again, a pure notion of social normativity, by its ahistorical, apolitical, decontextualized and depersonalized constitution, leads both to the standardization and massification of the social subjects, which can be substituted with institutional authorities, and to the centrality of impartial, neutral, formal and impersonal institutions that performs a model of minimal politics which is submitted to the civil society's apoliticity-privatization and, on the other hand, substitutes social classes and political struggles for a technical-logical institutionalism and its elites, putting strong and apolitical institutionalism as a substitute for the praxis.

Indeed, this is the first point we want to problematize: the massive tendency toward strong institutionalism, toward a model of pure (in the sense of independent and overlapped to social-political classes, struggles and belongings) and technical-logical, non-political and nonnormative notion of social system as a structure-arena-subject with no politicity, carnality and linking to nowadays life, to the current and conflictive social-political classes, struggles and dynamics. In this sense, institutions are the object and the subject of the political theories because these political theories deny the complete politicization of society by affirming the idea that the process of Western modernization basically means the consolidation of the private spheres of social life and reproduction which are centralized, monopolized and managed by self-referential, self-subsisting, autonomous and overlapped institutions or social systems that assume and streamline a very internal, technical-logical, non-political and non-normative functioning and programming which leads to their privatization and, therefore, depoliticization-apoliticity, 
depersonalization and decontextualization regarding the social world, the social-political classes and their struggles. Here contemporary liberal political theories refuse the complete politicization of society, its social-political classes, struggles, values, practices and institutions, by recognizing that there are spheres and subjects which are not political, but just private, apolitical, technicallogical. And, what is more important, they put the private-apolitical as basis of the political, as if Western modernization were and meant a process of consolidated privatization, anonimization, individualization, depersonalization and technicization of the institutions and, as basis of this, of the social classes, of the social-political struggles. Besides, if there are no social classes with a macro-structural sense and range, then a radical and direct political praxis concerning all social institutions is no longer valid for contemporary politics, which means that the current socialpolitical subjects are very individualized and anonymous, with no capability of a wide social action in the name of society as a whole. Now, from the individualization and the anonymity of the social-political classes, the political theory -in the moment that it can no longer use this notion of social class as the object and the subject of its analysis and prognostics - assume the institutions (and from this systemic standpoint above commented) as basis of its constructions and propositions. The strong institutionalism means that the central core and role of society are its institutions or social systems, and they are structures-arenas-subjects marked, as we already said, by a self-referential, self-subsisting, autonomous, closed, internal and overlapped dynamic of functioning and programing which is highly apolitical and depoliticized, highly depersonalized and decontextualized, just technical-logical, impartial, neutral, formal and impersonal regarding social belongings, social-political subjects, their clashes and hegemonies. That is the reason why a direct and radical political praxis from civil society's social-political subjects cannot substitute institutions' internal-closed and logical-technical dynamics, subjects, values and practices, which means that only indirect politics for both, civil society's subjects and political-juridical institutions, regarding social systems is possible in nowadays societies. As Habermas said about his theoretical-political position in relation to a possible political praxis for current functionally differentiated Western societies: politics is not all, is not the basic core and role of society as a whole, which is divided into many particular-closed and technical-logical social systems, as marked by individualization and anonimization of the social-political subjects, which means that institutionalism is the basis, the arena, the procedure and the subject of social-political legitimation, framing and changing, a kind of reformism which is always restricted and determined by these apolitical-depoliticized, private and technical-logical social systems, as by the privatization-apoliticity and depersonalization-decontextualization of the institutions concerning the social-political classes, by their complete disconnection and independence.

In fact, the interplay of a public sphere based in civil society with the opinion- and willformation institutionalized in parliamentary bodies and courts offers a good starting point for translating the concept of deliberative politics into sociological terms. However, we must not look on civil society as a focal point where the lines of societal self-organization as a whole would converge. Cohen and Arato highly emphasize the limited scope for action that civil society and the public sphere afford to noninstitutionalized political movements and forms of political expression. They speak of a structurally necessary "self-limitation" of radical democratic practice. First, a robust civil society can develop only in the context of a liberal political culture and the corresponding patterns of socialization, and on the basis of an integral private sphere; it can blossom only in an already rationalized lifeworld. Otherwise, populist movements arise that blindly defend the frozen traditions of a lifeworld endangered by capitalist modernization. In their forms of mobilization, these fundamentalist movements are as modern as they are antidemocratic. Second, within the boundaries of the public sphere, or at least of a liberal public sphere, actors can acquire only influence, not political power. The influence of a public opinion generated more or less discursively in open controversies is certainly an empirical variable that can make a difference. But public influence is transformed into communicative power only after it passes through the filters of the institutionalized procedures of democratic opinion- and will-formation and enters through parliamentary debates into legitimate lawmaking. The informal flow of public opinion issues in beliefs that have been tested from the standpoint of the generalizability of interests. Not influence per se, but influence transformed into communicative power legitimates political decisions. The popular sovereignty set communicatively aflow cannot make itself felt solely in the influence of informal public discourses - not even when these discourses arise from autonomous public spheres. To generate political power, their influence must have an effect on the democratically regulated deliberations of democratically elected assemblies and assume an authorized form in formal decisions. This also holds, mutatis mutandis, for courts that decide politically relevant cases. Third, and finally, the instruments that politics has available in law and administrative power have a limited effectiveness in functionally differentiated societies. Politics indeed continues to be 
the addressee for all unmanaged integration problems. But political steering can often take only an indirect approach and must, as we have seen, leave intact the modes of operation internal to functional systems and other highly organized spheres of action. As a result, democratic movements emerging from civil society must give up holistic aspirations to a self-organizing society, aspirations that also undergirded Marxist ideas of social revolution. Civil society can directly transform only itself, and it can have at most an indirect effect on the self-transformation of the political system [...]. But in no way does it occupy the position of a macrosubject supposed to bring society as a whole under control and simultaneously act for it (Habermas, 1998a, p. 371-372).

First of all, in order to understand the models of political theory assumed and defended by contemporary liberal political theories - in this case, Habermas; however, it serves also for the cases of John Rawls and Anthony Giddens (see Giddens, 1996; Giddens, 2000; Giddens, 2001), for example - and their direct relation-connection with institutionalism, we must reconstruct the concept of functionally differentiated society as meaning the current stage of the process of Western modernization. Now, the concept of Western modernization, in contemporary political theory in general and in Habermas in particular, signifies exactly (a) the consolidation of a process of self-differentiation, self-referentiality, self-subsistence and autonomy of many social systems (especially capitalist market and bureaucratic-administrative State), which acquire a technical-logical sense, dynamic, functioning and programing, becoming independent and overlapped in relation to politics, to political praxis, becoming, therefore, basically apoliticaldepoliticized, decontextualized-depersonalized, instrumental; (b) the decentralization of the society, which loses its unity, since, by the consolidation of many individualized and privatized institutions, politics is no longer the center of society, living side by side with these selfreferential and self-subsisting, non-political and non-normative social systems, which also means the fact that there are many principles of social integration, most of them technical-logical, and not only-nor fundamentally - politics and social normativity (that is the sense-meaning that politics is not the center of society neither as institution-subject nor as instrument and principle of institutional legitimation and functioning); (c) the individualization and the anonymity of the social-political classes, which means that the political subjects are very singularized ones, with no structural sense and range, with no class consciousness and belonging, incapable of assuming general interests in the name of society itself-we have in Western contemporary societies only individuals and social-cultural groups who live their specific worldview, putting politics as a peripheral instrument and context of society; (d) the consolidation and the constitution, by (unpolitical) pluralism and individual rights, of a private sphere of civil society that is not political, a depoliticized and privatized sphere of social reproduction that, on the one hand, blocks political intervention and, on the other, limits from an unpolitical standpoint what politics and political institutions can effectively do or not as politics and political institutions. Now, functionally differentiated societies, as the result of this process of Western modernization assumed by liberal political theories as the paradigmatic background for the understanding, construction and framing of the political theory of/for this notion of Western modernization, are societies (a) with no political center, societies where politics is not the basis of their constitution, legitimation and evolution; (b) with no social-political classes which assume a structural sense, range and action; (c) with many individualized, privatized and technical-logical social systems which are depoliticized; (d) with many principles of social, political and institutional integration, many of them technical-logical, non-political and non-normative (politics is not the only nor the central principle in a society characterized and defined by individualized, privatized and apolitical social systems); and (e) with a highly private civil society that is marked by a negative and egoistic, massified, depersonalized and decontextualized model of pluralism and individual rights that closes this civil society to political framing, legitimation and changing. In this sense, a functionally differentiated society, or a complex society, is a society characterized by a very great apolitical-depoliticized constitution, legitimation and evolution, as for individualized, standardized-massified and apolitical social subjects and for technical-logical social systems (with no class belonging and social-political linking) that put politics as a peripheral arena-basis and instrument of societal-institutional action. Functionally differentiated societies, complex societies, based on this systemic or institutionalist understanding of the process of Western modernization, therefore, are societies marked and defined by technical-logical institutionalism, and political-practical depersonalization and decontextualization, which leads to the limitation of politics due to the self-referentiality and self-subsistence of the social systems, the depoliticization and privatism of civil society and the anonymity and depersonalization of the social-political subjects. That is the reason for contemporary liberal political theories choosing 
institutionalism as object and subject of their theories of justice, as starting point, medium and final point for the construction, legitimation and social application of norms, practices and decisions binding for the mass of standardized subjects, subjects with no carnality, politicity, personalization and contextualization as social-political classes, as political subjects. In the case of Habermas, as we saw above, the correlation between formal spheres, subjects, practices and values (the institutions) and informal spheres, subjects, practices and values (civil society's context) is defined by the idea that it is the institutions that determine the validity of the socially binding rules and practices, so that social-political subjects cannot substitute for these politicaljuridical institutions, which become the medium between social systems (including the very juridical-political institutions) and the lifeworld. Of course, Habermas affirms both (a) a normative sense of political-juridical institutions, with their location into the lifeworld, and (b) an inclusive-participative democratic process of legitimation as basis of institutional action, which means that civil society can influence the institutional processes, authorities and powers. However, first, institutions are social systems, with a technical-logical constitution and functioning-programming, which signifies that a radical democracy cannot change institutions' technical-logical structuration nor their closure, self-referentiality and self-subsistence. Second, social movements and citizen initiatives, because they are not social-political classes in the Marxist sense, as structural subjects in terms of organization, range and action, cannot perform a direct, radical, inclusive and participative political praxis regarding social systems in general and in relation to political-juridical institutions in particular, substituting them or putting themselves in the same place that these institutions. In a situation of political individualization and anonymity, political-juridical institutions become the medium between systems and lifeworld; they become the object and the subject of the political theories, in the sense that their arenas, procedures, authorities, values and practices are the core and the role from which democracy is guaranteed, legitimized and streamlined. As a consequence, it is from within the institutions that the legitimate politics are made and applied, which means the peripheralization of civil society and its social-political subjects. In the same sense, a direct and radical political praxis from civil society's social-political subjects to social systems is denied because these social systems, in a functionally differentiated society, have a technical-logical, non-political and non-normative constitution, legitimation and evolution that privatize them, depoliticizing and making them basically closed, autonomous and overlapped to political praxis. As a conclusion, according to Habermas, from these theoretical assumptions regarding the current stage of the process of Western modernization (the centrality of the private, apolitical, decontextualized and depersonalized institutions or social systems, which become technical-logical, pure and formal structures-arenas-subjects with a self-referential, self-subsisting and autonomous constitution, functioning, programming and linking; the massification, standardization and individualizationanonymity of the social-political subjects, which become depersonalized-decontextualized), his political theory " $[\ldots]$ considers the political system neither apex nor center nor even the structural core of society, but just one action system among others" (Habermas, 1998a, p. 302).

Here, Habermas intends to save democracy from strong institutionalism and systemic depoliticization, but it is exactly the opposite that occurs. Indeed, the basic diagnosis that permeates Habermas's theory of modernity and his consequent juridical-political procedural paradigm as a model of radical democracy for contemporary complex societies is exactly the danger of strong institutionalism, in that the market colonizes the lifeworld and the State burocratizes civil society (and even science rationalizes and technicizes the lifeworld). Now, the alternative of Habermas is to restrict the action of these social systems by reinforcing the frontiers between market, State-law and lifeworld. This is the very important and problematic point of Habermas's political theory: the alternative we have to face strong institutionalism is to respect, affirm and emphasize the frontiers of these three spheres of social reproduction, so that the market cannot intervene into the State and the lifeworld, the State cannot directly intervene into the market and the lifeworld, and the lifeworld cannot politicize and normatize the market and the State as a whole. Here arises the sense of Habermas's proposal of the correlation of affirmation of reciprocal frontiers and indirect political intervention in terms of linking among State, market and lifeworld: respecting and taking seriously the singular, self-referential and self-subsisting constitution, legitimation, functioning and managing of the social systems mean to understand them as technical-logical structures-arenas-subjects, that is, as very depoliticized, instrumental and privatized instances. On the other hand, that is valid also for the relationship of the market and the State with the lifeworld: they cannot frame a normative sphere from a technical-logical standpoint (see Habermas, 2002b, pp. 493-506; Habermas, 2003b, pp. 147-148; Habermas, 1998b, pp. 13-25; Forbath, 1998, pp. 272-286; Scheuerman, 2002, pp. 63-64; Arnason, 2002, pp. 
18-19; Young, 2002, pp. 370-386; White, 1995, pp. 133-136; McCarthy, 1991, p. 132). But how is any correlation possible if we have a very hard separation between social systems (as technicallogical, non-political and non-normative institutions, subjects, procedures and arenas which are self-referential, self-subsisting, closed, autonomous and overlapped to civil society, its social classes and struggles) and a basically normative-political-cultural sphere of social reproduction? There is an impossible correlation here which has as direct consequence the fact that strong institutionalism is totally legitimized to become the central core and role of social systems regarding themselves and, more importantly, regarding civil society, which become nullified and blocked by this separation between technical-logical institutions and political-normative arena, subjects and practices. As we think, the solution for the problem of strong institutionalism is not the affirmation and the reinforcement of the frontiers between social systems and lifeworld, between public-political and private-apolitical, between technicality and politicity-carnality, but exactly the overcoming of these barriers and frontiers, which means the complete politicization of civil society and the institutions or social systems, as the necessity of personalization and contextualization of the social-political classes, their struggles and hegemonies as basis of a political theory that has the process of Western modernization as its main theme and content.

Strong institutionalism emphasizes the barriers and the frontiers between institutions and civil society as the basis of its centralization and monopolization of both political arena, procedures and subjects, and of the functioning and programming of the social systems themselves. A technical-logical constitution, legitimation and evolution of the social, political, economic and juridical institutions is possible only from their depoliticization, apoliticity, depersonalization and decontextualization regarding practical-political belongings, socialpolitical classes and clashes, as if institutions were independent of these social-political subjects, struggles and hegemonies, as pure structures-arenas-subjects with no politicity, carnality and belonging. This is the basic requirement for institutional self-referentiality, self-subsistence, autonomy, closure and overlapping in relation to civil society, its social-political classes, struggles and hegemonic dynamics; this is also the fundamental condition for the limitation, privatization and depoliticization of civil society, its social-political classes and struggles by strong institutionalism, in order to substitute civil society, the current social-political subjects and their clashes as basis, subject and practice for political foundation and social criticism by institutional dynamics, procedures, values, codes and technicians. Therefore, strong institutionalism sustains itself exactly by affirming and reinforcing the frontiers and particularities of the institutions regarding each other and principally concerning the lifeworld, concerning the civil society, differentiating very directly and purely what is a technical-logical, self-referential and selfsubsisting, autonomous and closed, depersonalized, decontextualized and apolitical institution versus the politics and the social-normativity. That is the basic principle of conservatism in nowadays politics regarding the understanding of the process of Western modernization, regarding the discussion about the sense and the resolution of the current crisis of this process of Western modernization, and it is surprising that Rawls, Habermas and Giddens, in the moment that they put institutionalism as ground, core and role of societal-institutional explanation and political foundation, must directly and indirectly accept that the technical-logical, non-political and non-normative constitution, managing, functioning and programing of the social systems is the starting point and the basis of definition of a political theory for democracy. In this sense, political praxis from civil society's social-political subjects is limited, framed and conditioned to institutionalism, so that political praxis cannot substitute institutionalism, becoming peripheral and submitted to this - politics is only possible after the technical-logical, self-referential, selfsubsisting, closed, autonomous and overlapped institutionalism; politics appears and is possible only when apolitical and depoliticized technical-logical social systems do not act or where they are not rooted (which means a minimal politics, in fact). As Rawls emphatically said, violent civil disobedience has not legitimacy, because of (a) institutionalism's specificity, (b) social subjects' political depersonalization, anonymity and individualization, (c) the existence in one same level of importance of many principles of social and institutional constitution, legitimation and evolution (not only politics and social normativity, but also technical-logical principles, subjects, arenas, values and instruments of functioning, managing and programming), and (d) civil society's privatism, depersonalization and decontextualization, which means a standardized, massified and decontextualized notion of social-political subject of action incapable of wide politicity in relation to institutions - only institutions have minimal capability to perform a socialpolitical framing and orientation, but from the limitation posed by self-referential, self-subsisting and technical-logical social systems, and by civil society's privatism, depersonalization and apoliticity. In the same sense, as we saw in Habermas's words cited above, the power lies with 
institutions, inside them, legitimized and streamlined from the institution's internal procedures, codes, values and self-authorized legal staffs, which means that for civil society's (individualized and anonymous) social-political subjects remain only the influence, the peripheral condition in relation to the centrality of the technical-logical institutionalism as the basic and definitive characteristic of the process of Western modernization, of the functionally differentiated contemporary societies (complex societies).

Indeed, where there are technical-logical, depersonalized and decontextualized structuresarenas-subjects, pure (because apolitical and instrumental, with no carnality, politicity and practical linking) institutions and self-authorized legal staffs, there are no possibility and space for political praxis, for inclusion and participation regarding the institution's constitution, legitimation and evolution. That is a fact for both juridical-political institutions and social systems in general, especially the market: their systemic structuration, that is, their selfreferentiality, self-subsistence, autonomy, closure and overlapping regarding politics and social normativity, enabled by their technical-logical, non-political and non-normative constitution, as for their privatization, leads to the centralization and monopolization of the procedures, values and subjects of foundation inside institutions, constructing a very hard and apolitical barrier between institutions and civil society, institutional self-authorized legal and technical staffs and civil society's social-political subjects, between institutional technicism and political praxis. Here, the argument that institutions work from a technical-logical standpoint which is not political nor normative, which requires specialized technicians and authorities, ensures the consolidation of a barrier and a frontier that cannot be crossed or changed by politics nor framed by social normativity. As a consequence, institutions can continually justify their autonomy, closure and overlapping regarding civil society and, in truth, conceive of civil society from a private, depersonalized, decontextualized and apolitical basis (by deleting the assumption of the notion of social-political classes), as well as they can frame juridical-political institutions (they are also systemic in a very strong way) in order to put the privatism-apoliticity-depersonalization as the fundamental principle that defines, determines and orientates what politics can and cannot do, how civil society's social-political subjects can and cannot act publicly, politically, institutionally. By also sustaining this contraposition between social systems and politics, developed from systems theory, Habermas cannot face the problem of strong institutionalism, the problem of systemic closure, self-referentiality, depoliticization and colonization concerning the lifeworld, because he exactly affirms the depoliticization, technicality and depersonalization of the social systems as their basic characteristics and conditions, which lead to their privatization. Now, as we said above, it is necessary to overcome this separation by the deconstruction of the apolitical, technical, decontextualized and depersonalized comprehension of institutions, civil society and social-political subjects taken and sustained by systems theory, a point that Habermas assumes and utilizes as basis for both his notion of Western modernization (as systemic selfdifferentiation, self-referentiality and self-subsistence of apolitical, private and closed modern institutions) and of his notion of political democracy for contemporary Western societies constituted and streamlined in terms of the juridical-political procedural paradigm as institutionalism (as well as Rawls and Giddens use as central core and role of their political theories - institutionalism as object and subject of the political theory).

The starting point for that, therefore, is to integrally politicize social systems or institutions, civil society and social-political subjects, by the recovery of the concept of praxis. This concept emphasizes and starts from the idea that the social-political subjects in their current struggles, oppositions, hegemonies and counterpoints make institutions, streamline wide social processes and dynamics - social-political subjects who must be politicized, personalized and contextualized. Here, institutions, values and practices are not made and defined from decontextualization, apoliticity and depersonalization regarding these social classes, their struggles, hegemonies and counterpoints. In this sense, there is not a pure structure-subject-arena with a non-political, non-normative and basically logical-technical or instrumental sense, constitution and dynamic, but institutions become the very result of social interactions, political conflicts and normative hegemonies and counterpoints performed by opposite and conflictive social-political classes, which means the centrality of the civil society's arenas, subjects, practices, values and clashes. Here, civil society becomes totally political and such a politicity - as a result of the interactions and conflicts between these social-political subjects - permeates the political-normative constitution, legitimation and social linking of the social systems, which means (a) the overcoming of the technical-logical comprehension of the social systems, as the deconstruction of their self-referentiality, self-subsistence, autonomy, closure and overlapping regarding civil society's political praxis and social classes; and (b) the 
politicization of the apolitical privatism, so that becomes unveiled that a negative, private and depoliticized notion of individual rights is the ideological complement of the concept of social systems as technical-logical, non-political, non-normative and privatized institutions, arenas, structures and subjects of civil society. The praxis, therefore, makes all political, devolving the ontogenetic centrality of civil society, for civil society, its social-political classes and clashes as basis of the societal-institutional constitution, legitimation and evolution, by denying the liberal privatism and apoliticity of the individual rights, the negative sense of pluralism and the technical-logical, self-referential, self-subsisting, closed and overlapped constitution of the social systems regarding political praxis and social normativity, regarding the social-political classes, their struggles, oppositions and hegemonies. As a consequence, political theory must go beyond strong institutionalism, overcoming and substituting it as a pure structure, arena and subject for the recovery and explanation of the social-political classes that streamline the dynamic, the constitution and the evolution of civil society, defining institutional designs, procedures, values and legitimized authorities. The praxis does not separate civil society and institutions, lifeworld and social systems, but conceive of them as the same societal context, as dependent moments of one more basic ontogenetic principle, which are the social-political classes in their struggles, oppositions and hegemonies. By doing that, the concept of praxis requires not only the assumption of these social-political classes, their struggles and hegemonies as the basis of the political foundation and institutional analysis, but also moves the scientific explanation of the social from institutionalism to civil society, since it conceives of civil society as the normativepolitical basis from which institutions gain form, sense, legitimation and linking, and that means that we must assume, if we want to overcome strong institutionalism in theoretical and political terms, the social classes, the class struggles and political oppositions and hegemonies as starting point for understanding both civil society's and institutions' movements, as for thinking an antisystemic and anti-institutionalist political praxis that politicizes all and everyone. In summary, if strong institutionalism privatizes and peripherizes civil society, its social-political classes, struggles and hegemonies in relation to the self-referentiality, self-subsistence, autonomy, closure and overlapping of the social systems, the praxis reemphasizes both the political-normative constitution and dynamic and the ontogenetic centrality of civil society in terms of generating and defining the institutions' designs and movements; if strong institutionalism makes institutions basically logical-technical, non-political and non-normative structures, arenas and subjects, as if they were pure, with no politicity, carnality and linking, the praxis conceives of social systems as political-normative arenas and structures which result from and are determined by social-political classes and their struggles for hegemony; if strong institutionalism centralizes and monopolizes all political decisions, social vindications and political participations inside these closed, autonomous and overlapped technical-logical institutions, the praxis returns to civil society's social-political subjects the power (not just the influence) of framing, criticizing, orienting and even changing the institutions, by refusing their technicality-apoliticity and autonomy-closureoverlapping, as their depersonalization and decontextualization regarding civil society's politicalnormative arena, and social-political classes and their praxis; and, finally, if strong institutionalism puts the decision power in the hands of institutional technicians and elites, and from an internal and instrumental procedure of foundation, managing and programming, beyond and minimizing the political participation and the social inclusion, the praxis devolves to socialpolitical classes the political-normative centrality in terms of construction of institutional designs and hegemonies.

That means, therefore, the necessity of politicization, personalization, contextualization and carnality of civil society, its social-political classes, practices, values and struggles, which become the basis of understanding, framing and changing of the institutions, that cannot be comprehended or legitimized without this very linking and dependence regarding civil society's political arena, subjects, praxis, struggles and hegemonies. Indeed, as we have shown above, the liberal political theories' most basic principles are (a) the technical-logical constitution, legitimation and social linking of the institutions or social systems, which signifies their selfreferentiality, self-subsistence, autonomy, closure and overlapping regarding political praxis and social normativity, becoming logical-technical, non-political and non-normative instances, as pure (in the sense of non-political and non-normative, independent and overlapped to socialpolitical classes, struggles and hegemonies, just technical-logical and closed) structures, arenas, dynamics and subjects. (b) As condition for such technicality, the depoliticization and closure of social systems, the unpolitical and privatized sense of civil society, which means that it is constituted as a grey and undefined zone between institutions and individuals or social groups, between politics and social systems that makes totally unclear what is political and what is not, so 
that the privatism and apoliticity point to and legitimize a model of minimal politics which is submitted to and framed and oriented by the apoliticity, privatism and technicality of both social systems, negative and unpolitical pluralism and apolitical and private individual rights. After all, if Rawls, Habermas and Giddens affirm the political sense of civil society, on the other hand, they put into the sphere constituted by it the technical-logical, apolitical and privatized social systems with an autonomous, closed and overlapped dynamic of functioning, legitimation and programming, the negative, problematic and even unpolitical pluralism and, finally, the individual rights as greatly negative, privatized and apolitical rights as defining a model of individualized, anonymous and non-political, massified, standardized, depersonalized and decontextualized subject. In this sense, (c) the technical-logical social systems and the apolitical and privatized civil society are complemented with a notion of anonymous, individualized and apolitical subject of foundation that puts privatism, apoliticity and technicality as basis of institutions' constitution, legitimation and evolution, by silencing about and refusing civil society's political structuration, by refusing to assume the notions of social class, class struggles and hegemonies as personalized, politicized and contextualized subjects, struggles and practices, by refusing, finally, to assume the concept of praxis as alternative to institutionalism. In truth, institutionalism is the direct consequence of the apolitical, depersonalized, decontextualized, privatized and formalist understanding of the social systems, civil society and social-political subjects. In this case, institutions as macro arenas, structures, dynamics and subjects are all that remains of the description of Western modernization, but a very neutral, impartial, depersonalized, decontextualized, privatized and apolitical one, with no social-political linking, with just a very weak correlation with praxis, with social classes, with social-political struggles and hegemonies. As a consequence, institutions are self-referential, self-subsisting, autonomous, closed and overlapped to civil society, as they can be legitimized and explained independently of civil society, of the social-political classes, struggles and hegemonies. Here, strong institutionalism appears as defining the sense and the social-political linking of institutions, as defining the sense of political liberalism and social-democracy as institutionalism, technicality and depoliticization (and they intend exactly the opposite).

The politicization of civil society by placing it as a political-normative sphere constituted and streamlined by personalized and political-normative subjects, as a political-normative sphere defined by social-political struggles, oppositions and hegemonies is the alternative for liberal political theories' strong, apolitical, depersonalized, decontextualized and technical institutionalism. A political-normative civil society means that social dynamics and institutions are forged, explained and streamlined for the concurrent social-political classes that constitute and move a society over time, which also signifies that social and political institutions are rooted in civil society exactly by and because of these concurrent social classes, their oppositions and struggles. In this sense, institutions' dynamics, relations and connections, social processes and political subjects become personalized and contextualized, avoiding the depersonalization, decontextualization and formalism of a technical-logical notion of social systems as a pure arena, structure and subject with no politicity, carnality and linking with civil society, its social-political classes, struggles and arenas (the basis of strong institutionalism). It also allows overcoming a standardized, massified, unidimensional, depersonalized, decontextualized and apolitical socialpolitical subject that is assumed by liberal and social-democratic political theories and justifies strong institutionalism comprehended from a systemic perspective and foundation - strong institutionalism as a technical-logical arena is complemented with a massified, depersonalized and decontextualized notion of social subjects, and that concept of massified-standardized socialpolitical subjects legitimizes strong institutionalism. Here, by politicization of civil society and the placing of institutions into a societal dynamics constituted, streamlined and defined by class struggles, contrapositions and hegemonies, it is possible to personalize and contextualize social diagnosis, political praxis and institutional dynamics by affirming the class identity and linking of the social-political subjects, which allows a theoretical explanation and a practical application of these contents that has effectiveness, direction and linking with emancipatory social-political subjects, so that overcoming the centrality of apolitical institutions as the impartial, neutral and formalist arena, structure and subject of politics, of political praxis, of civil society in its relations to economic, political and juridical institutions. As we think, it is impossible to explain, understand, link and legitimize the social systems' constitution, functioning and programming, as social systems' linking to civil society, without conceiving of them from a personalized, contextualized and political-normative rooting in civil society, and that requires the assumption of the social-political subjects which constitute and streamline civil society. In other words, without unveiling the social-political classes, without personalizing these social-political subjects who are 
the basis and establish the dynamics of institutions from civil society's struggles, oppositions and hegemonies, an effective, critical and emancipatory diagnosis and linking of political theory is impossible - it becomes institutionalism and points to it, legitimizes it, because such a kind of formalist, impartial, impersonal and formal proceduralism only finds in institutional technicality, depersonalization and apoliticity its effective diagnosis. In this case, a theory which does not politicize, personalize and contextualize the social-political classes as basis of societalinstitutional explanation, diagnosis and propositions, locating and inserting institutions into civil society as a political-normative sphere constituted and streamlined by social-political classes, their struggles, oppositions and hegemonies, can at most assume that institutions - from a technical-logical standpoint, with no politicity, carnality and linking with civil society's socialpolitical subjects, clashes, oppositions and hegemonies - work and act autonomously, closely and overlapped to civil society, but it cannot link them with nowadays political praxis, which depends on the personalization and contextualization of the social-political subjects and their struggles. Here, by personalization and contextualization of the social classes, institutions gain form, dynamic and sense. Without this, institutions lose their social-political-normative basis and linking, floating in a vacuum, in pure independence and autonomy of the personalized and contextualized social-political classes.

Now, by personalization and contextualization of the political theory and the social explanation into the civil society as a political-normative arena and the theoretical linking to civil society's social-political classes, struggles and hegemonies, it is possible to overcome both the civil society's and social systems' privatism, apoliticity-depoliticization and technicality, and the standardization, individualization and anonymity of civil society's epistemological-political subjects, avoiding their basic consequence, that is, strong institutionalism conceived of from an apolitical, technical, self-referential, self-subsisting, closed and autonomous standpoint and dynamic. First of all, in this case institutions are not pure, technical and apolitical structures, arenas and subjects which are closed, autonomous and overlapped to civil society's politicalnormative arena, social-political classes, struggles and hegemonies. Second, civil society's socialpolitical classes have name, personalization, which allows political theory to contextualize and politicize the subjects to which it is directed, from whom it is constructed. Third, the argument of institutional technicality based on the apolitical social rights and in the depoliticized zone constituted by civil society's social systems is deconstructed by the fact that institutions or social systems do not appear anymore in a vacuum, in a space with no politicity, carnality and socialpolitical linking; they are no longer technical-logical structures, arenas, dynamics and subjects which would be impartial, neutral, formal and impersonal regarding political praxis, social normativity and civil society's social-political subjects, but exactly the result of the class struggles, oppositions and hegemonies, which means that institutions are a construction of personalized social-political classes in their confrontations, oppositions and mutual reciprocities. As a consequence, the institutional framing, criticism and changing are not a matter for institutions' self-authorized legal staffs which act from a non-political, non-normative and technical-logical dynamic of functioning and programming, but a matter for an inclusive, participative and direct democratic political praxis which frames, criticizes and changes social systems from the basis of the affirmation of political-normative arguments which assume politics as the center of society, as the basis, the way and the instrument for social criticism and institutional constitution, legitimation and evolution. And more importantly, the understanding that civil society is a political-normative arena constituted and streamlined by conflictive and competing social classes with their struggles, oppositions and hegemonies, the consequent comprehension that institutions are not pure technical-logical structures, arenas and subjects, but located and rooted in the political-normative society as a product of class struggles, this leads to the affirmation of democratic political praxis as the arena, the way and the instrument of societalinstitutional framing, criticism, legitimation and changing; and, in consequence, this affirms the permanent, pungent, inclusive and direct participation as counterpoint to depoliticization, technicism, conservatism and fundamentalism, that is, the fact that social-political subjects must always and always participate in the public sphere, as political-normative subjects that politicize everything and everyone from the very basis that social relations and institutional designs are personalized, contextualized and, then, basically politicized, not neutral, impartial, impersonal and formal, but exactly a social practice which requires social-political subjects who are engaged into public-political sphere, as public-political subjects. Strong institutionalism, which is based on institution's purity and technicality regarding political praxis and social normativity, on institutions' depersonalization and decontextualization, and on civil society's apoliticity and privatism, as on social-political classes' apoliticity, anonimization and privatism, leads to self- 
referentiality, self-subsistence, autonomy, closure and overlapping of the institutions by denying the politicity of civil society and its social-political praxis, centralizing and monopolizing the institutions' functioning and programming into this model of pure technical-logical social system, assumed exclusively by the institutions' self-authorized legal staffs. Now, a radical democracy overcomes such technicality, privatism and apoliticity by putting as basis of civil society, political praxis and institutions the social-political classes, their struggles, oppositions and hegemonies. All depend on the politicization, personalization and contextualization of the social-political classes, all is based on this. Without that, there is no politics and political praxis, but only strong technical-logical, self-referential and self-subsisting institutionalism, independent, closed and overlapped to political praxis and social normativity exactly because it denies the politicization, the personalization and the contextualization of the social-political classes and their rooting into the civil society as a political-normative arena.

Conclusion

In conclusion, we want to argue in defense of a model of political anarchism that is a counterpoint to the institutionalism assumed and sustained by contemporary liberal political theories, an alternative also to the depoliticization and privatization of civil society and the anonimization and individualization of its social-political subjects constructed by these liberal political theories. In this sense, the first fundamental ideia which permeates political anarchism is that political praxis is the basis from which civil society and institutions gain form, dynamics and orientation. Here, there is no technicality, privatism, depersonalization and apoliticity, but exactly a very political ground, practice, value and dynamic. The second fundamental idea is that institutions are not independent-closed or overlapped to civil society's political-normative arena and social-political classes, their struggles, oppositions and hegemonies. Institutions are not pure structures, arenas and subjects, characterized by an internal proceduralism that is impartial, neutral, formal and impersonal regarding civil society's politicization, social classes, struggles, oppositions and hegemonies; likewise, they are not self-referential, self-subsisting and autonomous dynamics of functioning and programming regarding these political sphere, praxis and subjects constituted by and located in civil society, which means that social analysis and political praxis, if they want to be critical and emancipatory, must personalize, contextualize and politicize the social-political classes which constitute, streamline and determine societalinstitutional processes, dynamics, designs and hegemonic powers. Without such contextualization, personalization, politicization and linking among civil society (as politicalnormative arena), social-political classes and institutions, any possible theoretical analysis and political proposition is at most a technical and formalist analysis and proposition, because it ignores both the social-political linking of the institutions or social systems and the centrality of the social-political classes, their struggles, oppositions and hegemonies as the basis of the institutional constitution, legitimation and evolution. For political anarchism, the foundation of political theory, absolutely linked to and dependent on political praxis based on the notion of social-political classes, has a very direct way and a very pungent sense: from the politicity, carnality, contextualization and personalization of the social subjects, their struggles and oppositions, to the social, political, cultural and institutional arrangements, movements and processes. It is from a politicized, personalized and contextualized voice-praxis that criticism and social action are based on, streamlined and performed, which means both the centrality of the social-political classes and the theoretical necessity of bringing them into the political foundation - the social-political classes as object and subject of the political theories, denying institutionalism as object and subject of the political theories (as assumed by liberal political theories in contemporary times).

As a consequence, political anarchism has three basic points of orientation and streamlining, that is: (a) the necessity of personalization, contextualization and politicization of the institutions, linking them with civil society as a political-normative sphere, arena and dynamic; (b) the refusal of institutionalism as a structure, arena, practice and subject which is self-referential, self-subsisting, autonomous, closed and overlapped to civil society as a political arena constituted and streamlined by social-political classes, their struggles, oppositions and hegemonies, which also means that institutions are not technical-logical, non-political and nonnormative structures-dynamics, but exactly political-normative arenas; (c) the affirmation of the direct, inclusive and participative political praxis as the basis of institutional framing, criticism and changing, refusing a model of minimal politics which is submitted to and oriented by privatism-privatization-depoliticization of the social systems, civil society, unpolitical pluralism and negative individual rights; and (d) the affirmation of the social-political classes located in civil society as a political-normative arena and the subjects of societal-institutional constitution, 
streamlining and evolution over time by means of a radical and direct political praxis, so that avoiding the institutional proceduralism as an internal and technical-logical practice of managing, functioning and programming that assumes an apolitical-depoliticized, depersonalized and decontextualized movement which autonomizes institutions regarding political praxis and socialnormativity, by separating and making them independent concerning social-political subjects.

For political anarchism, it is very important - the decisive matter, in fact- the wide, radical and direct politicization of the civil society, its social-political classes and institutions, refusing the institutionalist model of politics and the technical-logical comprehension of the social systems assumed and fomented by liberal and social-democratic political theories, as John Rawls, Jürgen Habermas and Anthony Giddens, a model that directly or indirectly legitimizes political conservatism based on the systemic (that is, apolitical-depoliticized, decontextualizeddepersonalized and technical-logical) comprehension of the process of Western modernization and its basic social systems (market and State, fundamentally). Now, the politicization is allowed by personalization and contextualization of the social analysis and political praxis, that is, by the unveiling and use of the notion of social-political classes as basis for societal-institutional explanation, framing, criticism and changing. According to us, it is the notion of social-political classes as the subject and object of the political theory that enables both normative foundations and empirical diagnosis about dynamics, movements, ways and struggles of the process of Western modernization. Here, it is not a model of technical-logical, non-political and nonnormative, depersonalized and decontextualized institution or social system, or a model of formalist, impartial, neutral and impersonal proceduralism based on the lifeworld as a linguisticcultural-normative sphere individualized and anonymised in terms of its social-political classes, that can furnish and ground the possibility of a social analysis and a political praxis for Western modernization. A critical social theory which is also a model of radical democracy must assume (a) the complete politicization of civil society, its social-political classes and institutions and, as condition for that, (b) the personalization and contextualization of the political subjects as macrosocial classes, beyond individualization, anonymity and erasing of the class belonging and consciousness, which means the necessity of rejuvenation of the class analysis and propositions as the basis for the comprehension, framing, criticism and changing of the current stage of the process of Western modernization, which is characterized by depoliticization, depersonalization, decontextualization and privatism of the social systems and its colonization of politics from a technical-logical standpoint, something that can only be faced from the radical politicization and a direct, inclusive and participative political praxis which is the normative basis of societalinstitutional constitution, legitimation and evolution. For that, as we argued along the paper, it is necessary to deconstruct the strong institutionalism assumed and legitimized by contemporary liberal and social-democratic political theories, by the affirmation of the centrality of the socialpolitical classes in terms of societal-institutional constitution, legitimation and evolution.

\section{BIBLIOGRAPHICAL REFERENCES}

ARNASON, Johann P. "Deliberative democracy and the limits of liberalism". In: VON SCHOMBERG, René; BAYNES, Kenneth (Eds.). Discourse and democracy: essays on Habermas' Between Facts and Norms. New York: State University of New York Press, 2002.

CATROGA, Fernando. Entre deuses e césares: secularização, laicidade e religião civil - uma perspectiva histórica. Coimbra: Edições Almedina, 2006.

COLLINS, John J. A Bíblia justifica a violência? São Paulo: Paulinas, 2006.

CORBİ, Maria. "Constituent elements in the post-religional paradigm", Voices: Ecumenical Association of Third World Theologians (EATWOT), v. 35, n. 1, pp. 251-254, 2012.

DANNER, Leno Francisco; BAVARESCO, Agemir; DANNER, Fernando. "As diferenças como ethos e práxis contemporâneos: sobre a dialética entre fundamentação e aplicação de paradigmas normativoreligiosos", Horizonte, Belo Horizonte, v. 15, n. 46, pp. 510-542, $2017 \mathrm{a}$.

DANNER, Leno Francisco; BAVARESCO, Agemir; DANNER, Fernando. "Diferenças, politicidade e educação: em defesa da tensão produtiva em educação humanística”, pp. 53-91. In: DANNER, Leno Francisco; OLIVEIRA, Marcus Vinícius Xavier de; DANNER, Fernando; DORRICO, Julie (Orgs.). As diferenças no ensino de filosofia: reflexões sobre filosofia e/da educação. Porto Alegre: Editora Fi, 2017b.

DANNER, Leno Francisco. "The emergence of rationality: a philosophical essay", Conjectura: Filosofia e Educação, Caxias do Sul, v. 22, n. 1, pp. 11-31, 2017c.

DANNER, Leno Francisco. "Gênero e sexualidade na época do pluralismo: um desafio às religiões 
institucionalizadas e universalistas", Numen: Revista de Estudos e Pesquisa da Religião, Juiz de Fora, v. 19, n. 2, pp. 174-196, 2016a.

DANNER, Leno Francisco. "A crise das fundamentações universalistas: religiões universalistas e racionalismo ocidental em questão", Problemata: Revista Internacional de Filosofia, v. 7, n. 1, pp. 31-71, 2016b.

FORBATH, William E. "Short-circuit: a critique of Habermas' understanding of law, politics, and economic life", pp. 272-286: In: ROSENFELD, Michel; ARATO, Andrew (Eds.). Habermas on law and democracy: critical exchanges. Los Angeles: University of California Press, 1998.

FORST, Rainer. Contextos da justiça: filosofia política para além de liberalismo e comunitarismo. São Paulo: Boitempo, 2010.

GIDDENS, Anthony. Para além da esquerda e da direita: o futuro da política radical. São Paulo: Editora da UNESP, 1996.

GIDDENS, Anthony. A terceira via: reflexões sobre o impasse da social-democracia. Rio de Janeiro: Record, 2000 .

GIDDENS. A terceira via e seus críticos. Rio de Janeiro: Record, 2001.

HABERMAS, Jürgen. Teoria do agir comunicativo (Vol. I): racionalidade da ação e racionalização social. São Paulo: Martins Fontes, 2012a.

HABERMAS, Jürgen. Teoria do agir comunicativo (Vol. II): sobre a crítica da razão funcionalista. São Paulo: Martins Fontes, 2012b.

HABERMAS, Jürgen. Direito e democracia: entre facticidade e validade (Vol. I). Rio de Janeiro: Tempo Brasileiro, 2003a.

HABERMAS, Jürgen. Direito e democracia: entre facticidade e validade (Vol. II). Rio de Janeiro: Tempo Brasileiro, 2003b.

HABERMAS, Jürgen. A inclusão do outro: estudos de teoria política. Petrópolis: Vozes, 2002a.

HABERMAS, Jürgen. $O$ discurso filosófico-sociológico da modernidade: doze ensaios. São Paulo: Martins Fontes, 2002b.

HABERMAS, Jürgen. Between facts and norms: contributions to a discourse theory of law and democracy. Cambridge: The MIT Press, 1998a.

HABERMAS, Jürgen. "Paradigms of law", p. 13-25. In: ROSENFELD, Michael; ARATO, Andrew (Eds.). Habermas on law and democracy: critical exchanges. Los Angeles: University of California Press, 1998b.

HABERMAS, Jürgen. Ensayos políticos. Barcelona: Ediciones Península, 1997.

HABERMAS, Jürgen. Pensamento pós-metafísico: ensaios filosóficos. Rio de Janeiro: Tempo Brasileiro, 1990.

HABERMAS, Jürgen. Consciência moral e agir comunicativo. Rio de Janeiro: Tempo Brasileiro, 1989.

HABERMAS, Jürgen; RATZINGER, Joseph. Dialética da secularização: sobre razão e religião. Aparecida: Idéias e Letras, 2007.

HONNETH, Axel. Reificación: un estúdio en la teoria del reconocimiento. Buenos Aires: Katz, 2007.

HONNETH, Axel. Luta por reconhecimento: a gramática moral dos conflitos sociais. São Paulo: Editora 34, 2003.

MCCARTHY, Thomas. "Complexity and democracy: on the seducements of systems theory". In: HONNETH, Axel; JOAS, Hans (Eds.). Communicative action: essays on Habermas' The Theory of Communicative Action. Cambridge: The MIT Press, 1991.

MARRAMAO, Giacomo. Céu e terra: genealogia da secularização. São Paulo: Editora da UNESP, 1997.

MARRAMAO, Giacomo. Poder e secularização: as categorias do tempo. São Paulo: Editora da UNESP, 1995.

MONTEALEGRE, Deivit. "Change: significance and challenges", Voices: Ecumenical Association of Third World Theologians (EATWOT), v. 35, n. 1, pp. 135-139, 2012.

POPE FRANCIS. Amoris Laetitia. Vatican: Vatican Press, 2016. Access in: 08/09/2017. Available in:

http://m.vatican.va/content/dam/francesco/pdf/apost_exhortations/documents/papa-francesco_esortazioneap_20160319_amoris-laetitia_en.pdf

RAWLS, John. Uma teoria da justiça. São Paulo: Martins Fontes, 2000a.

RAWLS, John. Justiça e democracia. São Paulo: Martins Fontes, 2000 b.

RAWLS, John. O liberalismo politico. São Paulo: Ática, 2000c.

RAWLS, John. Justiça como equidade: uma reformulação. São Paulo: Martins Fontes, 2003.

ROBLES, José Armando. "A Copernican shift of religion and theology", Voices: Ecumenical Association of Third World Theologians (EATWOT), v. 35, n. 1, pp. 185-192, 2012.

RORTY, Richard. Uma ética laica. São Paulo: Martins Fontes, 2010.

SCHEUERMAN, William E. "Between radicalism and resignation: democratic theory in Habermas' Between Facts and Norms". In: VON SCHOMBERG, René; BAYNES, Kenneth (Eds.). Discourse and democracy: essays on Habermas' Between Facts and Norms. New York: State University of New 
York Press, 2002.

SYNOD OF BISHOPS. XIV ORDINARY GENERAL ASSEMBLY. "The vocation and the mission of family in the Church and in the contemporary world: the final report of the Synod of Bishops to the Holly Father, Pope Francis". Roman Curia, Vaticano, 2015. Disponível em: http://www.vatican.va/roman_curia/synod/documents/rc_synod_doc_20151026_relazione-finale-xivassemblea_en.html

140 VATTIMO, Giani. Depois da cristandade: por um cristianismo não religioso. São Paulo: Editora Record, 2004.

YOUNG, Iris Marion. "Comunicação e o outro: para além da democracia deliberativa", pp. 370-386. In: SOUZA, Jessé de (Org.). Democracia hoje: desafios para a teoria democrática contemporânea. Brasília: Editora da UNB, 2001.

WHITE, Stephen K. Razão, justiça e modernidade: a obra recente de Jürgen Habermas. São Paulo: Ícone, 1995. 